\title{
Fairness and Efficiency: Allowing Contribution Under ERISA
}

\author{
Elizabeth A. Di Cola $\uparrow$
}

In order to protect the security of private employee benefit plans, Congress passed the Employee Retirement Income Security Act (ERISA), which described certain judicially enforceable fiduciary duties. While the 1974 statute exposes a party to liability if it breaches its fiduciary duties, the law does not expressly grant a right of contribution-the right of a defendant who has discharged a common liability to recover reimbursement from other liable parties. The federal courts have varied in their willingness to infer such a right. Thus, the possibility exists that a single fiduciary may suffer liability disproportionate to its share of wrongdoing.

This Comment focuses on whether contribution should be allowed in the ERISA context. After surveying the inconsistencies in existing judicial decisions, the author looks to the values a contribution rule may implicate. On balance, she finds that the crucial aims of achieving fairness, efficiency, and proper levels of deterrence are better served by a rule permitting contribution. The author next considers how statutes involving securities, the environment, state tort law, and antitrust law have resolved the contribution issue. She concludes that legislative reasoning in each of these situations furthers the argument that contribution should be permitted under ERISA.

\section{INTRODUCTION}

With the much-publicized seizure of Executive Life-the largest insurance company ever to fail ${ }^{1}$ and a major repository of private pension monies ${ }^{2}$-and the resulting rash of lawsuits against corporate sponsors of retirement plans, ${ }^{3}$ the safety of workers' retirement funds has again cap-

$\dagger$ B.S. Finance 1981, University of Illinois, Urbana-Champaign; J.D. candidate 1993, Boalt Hall School of Law, University of California, Berkeley. I would like to thank the numerous individuals who generously offered encouragement, technical gnidance, and helpful comments on earlier drafts of this Comment. I am particularly grateful to Professor and Associate Dean John Dwyer of Boalt Hall; Mary Hipp and Scott Smith of Popham, Haik, Schnobrich \& Kaufman, Ltd., Minneapolis, Minnesota; Thomas Quinn of Schiff, Hardim \& Waite, Chicago, Illinois; and my colleagues at the California Law Review.

1. Kathy M. Kristof, Beleaguered Insurer Taken over by State, L.A. TiMEs, Apr. 12, 1991, at A1.

2. Kathy M. Kristof, Guaranteed Interest Accounts Aren't Risk-Free, L.A. TIMES, Dec. 15, 1991, at D4.

3. By the end of 1991 , suits alleging breach of fiduciary duty had been filed against Maxxam, 
tured public attention. No wonder-the safety and vibrancy of more than 737,300 private pension plans covering 78.2 million participants and holding over $\$ 1.9$ trillion in assets ${ }^{4}$ is no small matter. This Comment considers an issue intertwimed with the administration and availability of secure pensions: whether a right of contribution should be available to apportion liability among employee benefit plan fiduciaries who breach their fiduciary duties. ${ }^{5}$

Some background on the statute that governs employee benefit plans will place the issue in context. ${ }^{6}$ In 1974, Congress enacted the Employee Retirement Income Security Act (ERISA) ${ }^{7}$ in response to concerns that American workers were being demied retirement security because of weaknesses $\mathrm{m}$ the regulation of private pension plans. ${ }^{8}$ Congress was concerned that existing state law fiduciary standards did not adequately protect the financial soundness of pension and benefit plans. ${ }^{9}$ By replac-

Inc., Pacific Lumber Co., MagneTek, Inc., Unisys Corp., Honeywell, Inc., and AFG Industries. Jerry Geisel, Workers Sue Employers over Potential GIC Losses, Bus. INS., May 27, 1991, at 1 (on Unisys and Honeywel1); Pension Regulators Sue AFG Industries, L.A. TIMES, July 12, 1991, at D2 (on AFG Industries); Robert A. Rosenblatt, Make Good on Exec Life Losses, Firms Advised, L.A. TIMES, June 21, 1991, at D1, D7 (on Maxxam, Pacific Luniber, and MagneTek).

4. Michael ANZida, Questions ANd ANSwers on Employee Benefit Issues 8-9, 11 (Eniployee Benefit Research Institute Issue Brief No. 119, 1991) (citing various industry and government sources and using 1987 statistics).

5. Contribution is the term used to describe "a paynient made by each person, or by any of several persons, having a common interest or liability, of his share in the loss suffered or in the money necessarily paid by one of the parties in behalf of all the others." 18 AM. JUR. 2D Contribution $\S 1$ (1985). A "right of contribution" refers to "the right of one who has discharged a common liability or burden, to recover of another, also liable, the portion to which he ought to pay or bear," or "the right enjoyed by a person who is jointly liable with others and has paid more than his proper share in discharge of the joint liability to force then to reimburse hin to the extent of their liability." Id. In essence, then, contribution is a method of apportioning liability annong joint wrongdoers. In the litigation context, a right of contribution may, for example, permit a named party defendant to use a cross-clain or counterclaim to jom another party who should share any liability that is imposed on the named party defendant. See FED. R. CIV. P. 13 (governing counterclainis and cross-claims), 19-20 (governing joinder).

6. Enployee benefit plans include "employee welfare benefit plans" and "einployee pension benefit plans." 29 U.S.C. $\$ 1002(3)$ (1988). The term "employee welfare benefit plan" refers prinuarily to nedical and disability insurance. See id. $\S 1002(1)$. The term "employee pension benefit plan" refers to retirenuent programs, such as pension plans and 401 (k) programs. See id. $\S 1002(2)(\mathrm{A})$.

The availability of contribution is an issue in both the pension and non-pension employee benefit arenas. For ease of exposition, this Coniment considers the issue in the context of employee pension plans. The analysis is equally applicable to other types of fiduciary-managed employee benefit plans.

7. Enuployee Retirement Incone Seeurity Act of 1974 (ERISA), Pub. L. No. 93-406, 88 Stat. 832 (codified as amended at 29 U.S.C. $\$ \S 1001-1461$ (1988 \& Supp. II 1990)). ERISA governs all private "einployee benefit plan[s]." 29 U.S.C. § 1101(a) (1988).

8. See 119 CONG. REC. 130 (1973) (introductory remarks of Sen. Williains), reprinted in 1 Subcommittee on LABOR OF THE SENATE CoMm. on LABOR aNd PUb. Welfare, Legislative History OF THE EMPLOYEe RETIREMENT INCOME SECURITY ACT OF 1974, at $90-92$ (1976) [hereinafter LEGISLATIVE HISTORY OF ERISA].

9. See 29 U.S.C. $\$ 1001$ (a) (1988) ("[O]wing to the inadequacy of current minimum standards, the soundness and stability of plans with respect to adequate funds to pay promised benefits may be endangered."). During the hearings leading up to ERISA's enaetment, one focus 
ing varied state common law trust requirements with a unified federal law, Congress hoped to estabhish "judicially enforceable standards."10 Congress also sought to expand the availability of private pensions by using tax incentives to encourage corporate sponsorship of private pension plans. ${ }^{11}$

In order to protect employee benefit plan participants, ERISA requires plan fiduciaries to adhere to certain standards of conduct. ${ }^{12}$ Fiduciaries are required to act solely in the interest of participants, and with the "care, skill, prudence, and diligence" of a prudent person. ${ }^{13} \mathrm{~A}$

was misuse of employee benefit funds through diversions, overpayments for assets, excessive investments in employer securities, bribery, embezzlement, and kickbacks. See SENATE COMM. ON Fin., Private Pension Plan Reform, S. Rep. No. 383, 93d Cong., 1st Sess. 17-18 (1973), reprinted in 1 LEGISLATIVE HISTORY OF ERISA, supra note 8, at 1063, 1085-86.

10. 120 CONG. Rec. 29,951 (1974) (statement of Sen. Bentsen), reprinted in 3 LegiSLATIVE History of ERISA, supra note 8, at 4795; see also SENATE COMM. ON LABOR AND PUB. Welfare, Retirement INCOME SECURITy For EMPloyees ACT of 1973, S. ReP. No. 127, 93d Cong., 1st Sess. 29 (1973), reprinted in 1 Legislative HistoRY OF ERISA, supra note 8, at 587, 615 ("[A] fiduciary standard embodied in Federal legislation is considered desirable because it will bring a measure of uniformity in an area where decisions under the same set of facts may differ from state to state.").

11. Senate Comm. on Fin., Private Pension Plan Reform, S. Rep. No. 383, 93d Cong., 1st Sess. 10-11 (1973), reprinted in 1 LEGISLATIVE HISTORY OF ERISA, supra note 8, at 1063, 107879. By all indications, ERISA has encouraged the expansion of the private pension system. From 1975 to 1987 , the number of participants in private pension plans grew from 44.5 million to 78.2 million workers. ANZIDA, supra note 4, at 9 . The number of private pension plans increased from 311,100 to 733,000 during the same period. Id. at 8 .

While this Comment focuses primarily on an issue relating to fiduciary regulation, Congress' auxiliary goal of private retirement system expansion is nonetheless relevant. An effective policy deeision regarding the availability of contribution to ERISA fiduciaries should consider the dual purpose of the statute. See infra Section III.B.

12. Under ERISA, a person is a fiduciary with respect to any employee benefit plan to the extent:

(i) he exercises any discretionary authority or discretionary control respecting management of such plan or exercises any authority or control respeeting management or disposition of its assets, (ii) he renders investment advice for a fee or other compensation ... . with respect to any moneys or other property of such plan, or has any authority or responsibihity to do so, or (iii) he has any discretionary authority or discretionary responsibility in the administration of such plan.

29 U.S.C. $\$ 1002(21)(A)$ (1988). Sponsoring employers, investment managers, and trustees are all fiduciaries under ERISA. Id. $\S \S 1002(38)$ (investment managers), 1102(a)(2) (employers), 1103(a) (trustees).

13.

[A] fiduciary shall discharge his duties with respect to a plan solely in the interest of the participants and beneficiaries and-

(A) for the exclusive purpose of:

(i) providing benefits to participants and their beneficiaries; and

(ii) defraying reasonable expenses of admimistering the plan;

(B) with the care, skill, prudence, and diligence under the circumstances then prevailing that a prudent man acting in a hike capacity and familiar with such matters would use in the conduct of an enterprise of a like character and with like aims;

(C) by diversifying the investments of the plan so as to minimize the risk of large losses, unless under the circumstanees it is clearly prudent not to do so; and

(D) in accordance with the documents and instruments governing the plan .... Id. § 1104(a)(1) (1988 \& Supp. II 1990). 
fiduciary who breaches his fiduciary duties is personally hable to the plan for damages. ${ }^{14}$ In certain circumstances, a breach of fiduciary duty by one fiduciary may also constitute a breach of fiduciary duty by another fiduciary. ${ }^{15}$ In addition, fiduciaries can be jointly and severally liable for damages caused by breaches of fiduciary duties by co-fiduciaries. ${ }^{16}$

The management and administration of an employee benefit plan involve numerous entities with interrelated responsibihities. The legislative history and the terms of the statute suggest that Congress anticipated the possible involvement of trustees, investment managers, corporate plan sponsors, and investinent cominittees-each of whom is a plan fiduciary. ${ }^{17}$ But while ERISA anticipates the possibility of more than one breaching fiduciary, the statute is not clear about the availability of contribution among breaching fiduciaries. Congress did not expressly provide for rights of contribution under the statute, ${ }^{18}$ and courts addressing the question of whether to imply a right of contribution have split on the issue. ${ }^{19}$

Unlike the issue of contribution under antitrust, securities, or environmental law, ${ }^{20}$ little has been written about the right of contribution

14. Id. § 1109(a) (1988).

15. Id. $\S 1105$. A fiduciary is liable for a co-fiduciary's breach if such fiduciary knowingly participates in or undertakes to conceal an act or omission of the co-fiduciary; enables the cofiduciary to breach by breaching his own responsibilities; or has knowledge of the co-fiduciary's breach and does not make reasonable efforts to remedy the breach. Id. $\S 1105(\mathrm{a})$.

16. Although ERISA does not explicitly provide for joint and several liability, the courts have provided for such liability. See, e.g., Lowen v. Tower Asset Management, Inc., 829 F.2d 1209, 1221 (2d Cir. 1987) ("All defendants are ... jointly and severally liable ...."); Donovan v. Mazzola, 716 F.2d 1226, 1235 (9th Cir. 1983) (same); Katsaros v. Cody, 568 F. Supp. 360,369 (E.D.N.Y. 1983) (trustee jointly liable with other trustees for loss to the fund), aff'd, 744 F.2d 270 (2d Cir.), cert. denied, 469 U.S. 1072 (1984). A fiduciary is jointly and severally liable for damages caused by a breaching co-fiduciary even if the co-fiduciary provisions of $\S 1105$ are inapplicable.

17. See 29 U.S.C. $\S 1002$ (16)(B) (1988) (plan sponsors); id. $\S \S 1002(21)(\mathrm{A}), 1002(38), 1105$ (d) (investment managers); id. $\S \S 1102(\mathrm{c}), 1103(\mathrm{a}), 1105(\mathrm{~b})$-(c) (trustees); H.R. CoNF. REP. No. 1280, 93d Cong., 2d Sess. 323 (1974), reprinted in 1974 U.S.C.C.A.N. 5038, 5103 (fiduciaries include a plan's officers and directors, the investment committee, and the individuals who appoint the officers, directors, and committee members).

18. No mention of contribution is made in 29 U.S.C $\S 1132$, which sets out ERISA's civil enforcement provisions.

19. For a discussion of the cases analyzing this question, see infra Sections I.A-B.

20. The literature discussing contribution under securities, antitrust, and environmental law is extensive. In the antitrust area, two frequently cited works are Frank H. Easterbrook et al,, Contribution Among Antitrust Defendants: A Legal and Economic Analysis, 23 J.L. \& ECON. 331 (1980); A. Mitchell Polinsky \& Steven Shavell, Contribution and Claim Reduction Among Antitrust Defendants: An Economic Analysis, 33 STAN. L. REv. 447 (1981).

Among the articles discussing contribution under securities law are M. Patricia Adamski, Contribution and Settlement in Multiparty Actions Under Rule 10b-5, 66 IowA L. REv. 533 (1981); James M. Fischer, Contribution in 10b-5 Actions, 33 Bus. LAw. 1821 (1978); Mark J. Loewenstein, Implied Contribution Under the Federal Securities Laws: A Reassessment, 1982 Duke L.J. 543.

Contribution under the Comprehensive Environmental Response, Compensation, and Liability Act (CERCLA) and the Superfund Amendments and Reauthorization Act of 1986 (SARA) is discussed by Ellen J. Garber, Federal Common Law of Contribution Under the 1986 CERCLA 
under ERISA. ${ }^{21}$ A student Note written in 1990 analyzed then-existing case law to determine whether federal courts were einpowered to infer a right of contribution under ERISA. ${ }^{22}$ The author, disagreeing with the majority view, concluded that the court may use its equitable discretion to infer a right of contribution in cases where an ERISA trustee is a passive actor and is made to bear inost of the liability through strategy or accident. ${ }^{23}$

This Comment, in contrast, focuses primarily on pohicy: it addresses whether contribution should be allowed under ERISA, rather than whether it is currently available. I approach this question from two different perspectives. First, considering ERISA's particular structure and purposes, do the policy arguments favoring contribution have enough force to justify the creation of a right of contribution under ERISA? This approach considers tlie rationales advanced for and against contribution: fairness, efficiency, and overdeterrence. The second approach, taking its cue from the concept of a "legislative common law"24 espoused by Dean Landis ${ }^{25}$ and later advanced by Calabresi, Traynor, and others, ${ }^{26}$ considers wliether trends in statutory enactment evince a pro-contribution legislative policy that slould be given effect in ERISA. I consider four statutory regimes where the issue of contribution is settled: three that allow contribution-federal securities law, ${ }^{27}$ federal environmental $1 \mathrm{law}^{28}$ and state tort $\mathrm{law}^{29}$-and one that does not-federal antitrust law. ${ }^{30}$

Part I of this Comment discusses the current state of the law in liglit of the Second Circuit's decision in Chemung Canal Trust Co. v. Sovran

Amendments, 14 ECOLOGY L.Q. 365 (1987); Dale Guariglia, Apportionment and Contribution Under the "Superfund" Act, 53 UMKC L. REv. 594 (1985).

21. See Paul J. Hunt, Note, Bucking the Trend: An Argument in Favor of a Fiduciary's Implied Right to Contribution Under ERISA, 76 VA. L. REv. 1377 (1990). To date, this appears to be the only discussion of the issue in the academic literature.

22. Id. at $1388-95$.

23. Id. at 1407 \& passim.

24. See 2A Norman J. Singer, Statutes AND Statutory Construction $\S 45.10$ (4tli ed. 1984).

25. James M. Landis, Statutes and the Sources of Law, in HARVARd Legal ESSAYs 213 (Roscoe Pound ed., 1934).

26. See Guido Calabresi, A Common Law for the Age of Statutes (1982); Roger J. Traynor, Statutes Revolving in Common-Law Orbits, 17 CATH. U. L. REV. 401 (1968); Robert F. Williams, Statutes as Sources of Law Beyond Their Terms in Common-Law Cases, 50 GEo. WASH. L. REv. 554 (1982). For a discussion of the use of statutes beyond their terms as sources of law and statements of evolving legislative policy, see infra Section IV.A.

27. Securities Act of 1933,15 U.S.C. $\$ \S 77 a-77 a a$ (1988 \& Supp. III 1991); Securities Exchange Act of 1934, 15 U.S.C. $\S \S 78 a-7811$ (1988 \& Supp. III 1991).

28. Comprelensive Environmental Response, Compensation, and Liability Act of 1980 (CERCLA), 42 U.S.C. $\$ \$ 9601-9675$ (1988) (as amended by the Superfund Amendments and Reautlorization Act of 1986 (SARA), Pub. L. No. 99-499, 100 Stat. 1613).

29. See, e.g., UNIF. CONTRIBUtion AMONG TORTFEASORS ACT, 12 U.L.A. 57 (1975).

30. Sherman Act, 15 U.S.C. $\S \S 1-7$ (1988 \& Supp. III 1991); Clayton Act, 15 U.S.C. §§ 12-21, 22-27, 44 (1988 \& Supp. III 1991). 
Bank/Maryland. ${ }^{31}$ Part II reviews the ongoing discussion among lawand-economics scholars about the economic efficiency of contribution and considers the efficiency aspects of allowing contribution under ERISA. Part III argues that in ERISA's particular statutory scheine, fairness and overdeterrence considerations in favor of contribution outweigh efficiency arguments against contribution. Part IV suggests that legislative trends demonstrate a pro-contribution policy that should be given effect in the ERISA context.

CONTRIBUTION UNDER ERISA: CURRENT LAW

Because ERISA does not expressly create a right of contribution, courts have focused on whether a right of contribution can be implied from the terms of the statute or whether it can be inported froin coinmon law trust primciples. ${ }^{32}$ Federal courts addressing these arguments have reached conflicting conclusions. ${ }^{33}$

\section{A. The Availability of Contribution Before Chemung}

Prior to the Second Circuit's decision in Chemung, most courts had concluded that the federal courts had no authority to inply a right of contribution under ERISA. ${ }^{34}$ The primary exception was the Seventh

31. 939 F.2d 12 (2d Cir. 1991), cert. denied, 112 S. Ct. 3014 (1992).

32. In Northwest Airlines, Inc. v. Transport Workers Union, 451 U.S. 77 (1981), the Supreme Court stated that a right to contribution under a federal statute could arise either through affirmative creation of the right by Congress, explicitly or implicitly, or by judicial fashioning of a federal common law remedy. Id. at 90.

33. Compare Kim v. Fujikawa, 871 F.2d 1427, 1432-33 (9th Cir. 1989) (concluding that contribution is not available under ERISA) with Chemung, 939 F.2d at 15-18 (reaching the opposite conclusion).

34. See Kim, 871 F.2d at 1432 (holding that ERISA "cannot be read as providing for an equitable remedy of contribution in favor of a breaching fiduciary"); see also Schloegel v. Boswell, 766 F. Supp. 563, 569 (S.D. Miss. 1991) ("[T]his Court . . . declim[es] to engraft upon ERISA the remedies of contribution and/or indemnification."); Physicians Healthchoice, Inc. v. Trustees of the Automotive Employee Benefit Trust, 764 F. Supp. 1360, 1364-65 (D. Minn. 1991) ("[N]o right of contribution or indemnity among ERISA fiduciaries can be found in ERISA."); Hunt v. Magnell, 766 F. Supp. 727, 730 (D. Minn. 1990) (concluding that the Eighth Circuit "likely would adopt the view of the Ninth Circuit and various district courts in other circuits that ERISA does not provide fiduciaries with a cause of action for contribution against co-fiduciaries'); Narda, Inc. v. Rhode Island Hosp. Trust Nat'l Bank, 744 F. Supp. 685, 698 (D. Md. 1990) (concluding that Congress did not authorize the courts to incorporate common law rights of contribution and indeinnity); Mutual Life Ins. Co. v. Yampol, 706 F. Supp. 596, 600 (N.D. Ill. 1989) (holding that "ERISA does not provide for a right of contribution").

Although the concepts of contribution and indemnity are legally distinct, a discussion of their differences is beyond the scope of this Comment. The policy considerations are sufficiently sinilar for the concepts to be treated as one for purposes of this Comment. Courts addressing the issue presented here have focused on the availability of both a right of contribution and a right to indemnity. See, e.g., Schloegel, 766 F. Supp. at 565 ("[T]he issue is whether the courts will mcorporate the contribution and indemnity principles of common law into the statutory scheme of ERISA."); Physicians Healthchoice, 764 F. Supp. at 1362 ("[T] he Court must confine itself to the 
Circuit, which recognized a right of indemnity available through the court's equitable powers. ${ }^{35}$ As noted above, courts have employed two strands of analysis: (1) an implied cause of action theory, and (2) an incorporation of common law trust principles theory.

The analytical bedrock of the imphed cause of action theory is the methodology established by the Supreme Court in Cort v. Ash ${ }^{36}$ for determining whether a right of action should be implied from a federal statute. In Cort, the Supreme Court set out four factors for determining whether there is an implied cause of action under a federal statute: (1) whether the plaintiff is a member of tlie class for whose benefit the statute was enacted; (2) whetler there is an explicit or implicit legislative intent to create or deny the remedy sought; (3) whether such a remedy would be consistent witli the underlying purposes of the statute; and (4) whether the cause of action is one traditionally relegated to state law. ${ }^{37}$ ERISA contribution cases focusing on the implied cause of action strand have rehed on the Supreme Court's analysis in Northwest Airlines, Inc. v. Transport Workers Union ${ }^{38}$ and Massachusetts Mutual Life Insurance Co. v. Russell. ${ }^{39}$ Those two decisions applied the four Cort factors to determine whether Congress imtended to create an unexpressed remedy. ${ }^{40}$

In addressing their ability to imply a right of contribution under ERISA, courts have merged Cort's test of congressional intent as articulated in Northwest Airlines witl Russell 's imterpretation of ERISA's remedies language. Given a perceived legislative intent to benefit plan participants and not fiduciaries, ${ }^{41}$ and ERISA's "interlocking, interre-

express terms of ERISA and its surrounding body of common law to determine the validity of defendants' counterclaim for contribution or indemnity.").

35. See Free v. Briody, 732 F.2d 1331, 1337 (7th Cir. 1984) ("An award of indemnification within the himited circumstances of this case appears to us to be properly within the court's equitable powers."); Altou Memorial Hosp. v. Metropolitan Life Ins. Co., 656 F.2d 245, 250 (7th Cir. 1981) (suggesting in dicta that an ERISA fiduciary may seek contribution or indemnity from cofiduciaries).

The Seventh Circuit cases favoring contribution have not been followed. The Alton reference to contribution was dicta, and Free has beeu criticized because it was decided before Massachusetts Mutual Life Insurance Co. v. Russell, 473 U.S. 134 (1985), a key Supreme Court case addressing creation of private causes of actiou under ERISA.

36. 422 U.S. 66 (1975).

37. Id. at 78 .

38. 451 U.S. 77 (1981).

39. 473 U.S. 134 (1985); see, e.g., Schloegel v. Boswell, 766 F. Supp. 563, 566-69 (S.D. Miss. 1991); Physicians Healthchoice, Inc. v. Trustees of the Automotive Employee Benefit Trust, 764 F. Supp. 1360, 1362-63, 1365 (D. Minn. 1991); Mutual Life Ins. Co. v. Yampol, 706 F. Supp. 596, 59899 (N.D. Ill. 1989); see also Kim v. Fujikawa, 871 F.2d 1427, 1432-33 (9th Cir. 1989) (citing Russell but not citing Northwest Airlines).

40. See Russell, 473 U.S. at 145-48 (ERISA remedy); Northwest Airlines, 451 U.S. at 91 (Equal Pay Act and Title VII remedies).

41. See Kim, 871 F.2d at 1433 ("[I]mplying a right of contribution is particularly inappropriate where, as in this case, the party seeking contribution 'is a member of the class [e.g., fiduciaries] whose activities Congress intended to regulate for the protection and benefit of an 
lated, and interdependent remedial scheine, which is in turn part of a "coinprehensive and reticulated statute," $" 42$ courts have concluded that "Congress did not intend to authorize other remedies . . . that it simply forgot to incorporate expressly." "43 They have therefore almost uniformly concluded that the federal courts have no power to imply a right of contribution under the statute. ${ }^{44}$

The second strand of analysis-incorporation of a common law right of contribution - has produced inixed results. This argument relies heavily on the Supreme Court's reasoning in Texas Industries, Inc. v. Radcliff Materials, Inc. ${ }^{45}$ and Firestone Tire \& Rubber Co. v. Bruch. ${ }^{46}$ In Texas Industries, the Court noted that federal courts have the authority to formulate a "federal common law" only when a federal rule of decision is "necessary to protect uniquely federal interests," "47 or when "Congress has given the courts the power to develop substantive law."48 In Firestone, the Court decided to use trust law primciples for guidance in determining the appropriate standard of review, a decision consistent with its holding in a previous ERISA case that courts are to develop a " 'federal common law of rights and obhgations under ERISA-regulated plans." "49 Adopting these primciples, a court may reason from ERISA's legislative history that Congress wanted the courts to create a federal

entirely distinct class [e.g., ERISA plans]." ") (quoting Texas Indus., Inc. v. Radcliff Materials, Inc., 451 U.S. 630, 639 (1981); Piper v. Chris-Craft Indus., Inc., 430 U.S. 1, 37 (1977)) (emphasis omitted).

42. Russell, 473 U.S. at 146 (quoting Nachman Corp. v. Pension Benefit Guar. Corp., 446 U.S. 359,361 (1980)).

43. Kim, 871 F.2d at 1432 (quoting Russell, 473 U.S. at 146); Yampol, 706 F. Supp. at 598 (same).

44. See, e.g., Kim, 871 F.2d at 1432-33.

45. 451 U.S. 630 (1981).

46. 489 U.S. 101 (1989).

47. Texas Indus., 451 U.S. at 640 (quoting Banco Nacional de Cuba v. Sabbatino, 376 U.S. 398, 426 (1964)).

48. Id.

49. Firestone, 489 U.S. at 110 (quoting Pilot Life Ins. Co. v. Dedeaux, 481 U.S. 41,56 (1987)). In Firestone, the Supreme Court sought to resolve a conflict among the circuits regarding the appropriate standard of review for ERISA $\S 1132(a)(1)(B)$ actions challenging benefit eligibility determinations. Id. at 108. ERISA itself did not explicitly set out the appropriate standard of review for actions under $\$ 1132(\mathrm{a})(1)(B)$. Id. at 109.

In considering whether to adopt the arbitrary and capricious standard from the Labor and Management Relations Act of 1947 or trust law's de novo standard, the Firestone Court noted that "ERISA abounds with the language and terminology of trust law. . . . [Its] legislative history confirms that the Act's fiduciary responsibility provisions 'codif[y] and mak[e] applicable to [ERISA] fiduciaries certain principles developed in the evolution of the law of trusts.' " Id. at 110 (quoting H.R. REP. No. 533, 93d Cong., 1st Sess. 11 (1973)) (citations omitted).

In Pilot Life, the Court held that "[Congress'] expectations that a federal common law of riglits and obligations under ERISA-regulated plans would develop .... would make little sense if the remedies available to ERISA participants . . . could be supplemented or supplanted by varying state laws." 481 U.S. at 56. Despite this seemingly broad mandate under the reasoning of Pilot Life and Firestone to incorporate the common law of trusts into ERISA, other courts have read those decisions more narrowly. See infra note 50 and accompanying text. 
common law of ERISA by mcorporating common law trust principles including contribution among fiduciaries. Until the Second Circuit's decision in Chemung, however, most courts had rejected this approach, as they viewed their authority to incorporate trust law as limited. ${ }^{50}$

\section{B. Importing Trust Law Principles: A Common-Law-Based Right of Contribution in the Second Circuit}

In Chemung, the Second Circuit began by rejecting the apphicability of the Cort v. Ash analysis. ${ }^{51}$ The court reasoned that a right of contribution is not a "right of action" in the traditional sense addressed by Cort. ${ }^{52}$ The Chemung court saw contribution as a remedy that existed outside the relationship between ERISA's intended beneficiaries and ERISA's regulated class. ${ }^{53}$ Because inter-fiduciary relationships were not the focus of Congress' attention, the court reasoned, the availability of contribution was not withm the range of congressional intent discernible with the Cort tests. ${ }^{54}$

Having distinguished Cort, ${ }^{55}$ the Chemung court focused on its ability to incorporate a contribution reinedy through the federal common law. ${ }^{56}$ The keystone of the court's analysis was Firestone. The court adopted the Supreme Court's admonition in Firestone that " "courts are to develop a "federal common law of rights and obligations under ERISA-regulated plans" ' " and its statement that ERISA's fiduciary

50. See, e.g., Call v. Sumitomo Bank, 881 F.2d 626, 631-32 \& n.11 (9th Cir. 1989) (recognizing the importance of the common law of trusts in interpreting ERISA but affirming the District Court's holding that ERISA does not provide for a contributiou remedy); Schloegel v. Boswell, 766 F. Supp. 563, 565-66 (S.D. Miss. 1991) (focusing on specific language in Firestone, 489 U.S. at 110, which notes that the fiduciary provisions of ERISA codify only "certain" trust law principles) ; Hunt $v$. Magnell, 766 F. Supp. 727, 730 (D. Minn. 1990) (noting that ERISA's legislative history reveals a congressional intent to codify certain principles of the common law of trusts, but emphasizing that ERISA makes no specific reference to contribution); Narda, Inc. v. Rhode Island Hosp. Trust Nat'l Bank, 744 F. Supp. 685, 698 (D. Md. 1990) (acknowledging this line of reasoning as a valid one, but concluding that "the directive to develop a federal common law under ERISA does not include the right to infer common law rights of contribution").

51. Chemung Canal Trust Co. v. Sovran Bank/Md., 939 F.2d 12, 15 (2d Cir. 1991), cert. denied, 112 S. Ct. 3014 (1992).

52. The court noted that there is a significant difference between a right of contribution, which it characterized as "a procedural device for equitably distributing responsibility for plaintiff's losses," and a right of action, which involves the chance "to sue in the first instance." Id. at 15-16. Cort addressed the latter situation. The case involved an evaluation of whether a stockholder could bring a private lawsuit against a corporation for violating the Federal Elections Campaign Act. Cort v. Ash, 422 U.S. 66, 68 (1975).

The Chemung court admitted that if Cort applied, it would "cause an automatic dismissal of [the contribution claim]" because the claimant was not a member of the class that ERISA was designed to protect. Chemung, 939 F.2d at 15.

53. Chemung, 939 F.2d at 18.

54. Id.

55. Id.

56. Id. at 16-18. 
provisions codify principles developed in traditional trust law. ${ }^{57}$ After confirming that traditional trust law allowed contribution, ${ }^{58}$ the court concluded that it was appropriate to recognize a right of contribution as part of ERISA. ${ }^{59}$

Finally, the Chemung court distinguished Northwest Airlines, Texas Industries, and Russell. ${ }^{60}$ The court inaintained that neither Northwest Airlines nor Texas Industries was an impediment to its conclusion because, unlike the legislative history of ERISA, the legislative histories of the antitrust laws, Title VII, and the Equal Pay Act did not authorize the federal courts to develop a federal common law. ${ }^{61}$ The court then noted that $R$ ussell did not address the availability of federal common law remedies for fiduciaries, who "are granted no express personal remedies" under ERISA. ${ }^{62}$ The court concluded by reasoning that, although Congress' silence could be interpreted as intentional inaction, "[a] more likely inference is that when it came to reniedies under ERISA, congress [sic] simply did not focus its attention beyond the welfare of the plan's participants and beneficiaries."63

\section{The Absence of a Realistic Policy Discussion}

Policy issues lave not been dispositive in the battle over whether federal courts have authority to infer a right of contribution under ERISA. As one court noted:

These [policy] arguments [im favor of contribution] are not unpersuasive and would be substantial reasons for law makers to consider the inclusion of indemnification or contribution. In this context, however, they must be addressed to Congress. The

57. Id. at 16 (quoting Firestone Tire \& Rubber Co. v. Bruch, 489 U.S. 101, 110 (1989); Pilot Life Ins. Co. v. Dedeaux, 481 U.S. 41, 56 (1987)).

58. Id.

59. Id.

60. Id. at $17-18$.

61. Id. at 16-17. In both Texas Industries and Northwest Airlines, the Court made specific reference to the particular statutory scheme at issue. In Texas Industries, the Court failed to find a mandate from Congress to create a federal comnon law of antitrust remedies. Texas Indus., Inc. v. Radcliff Materials, Inc., 451 U.S. 630, 644-45 (1981). The Court therefore concluded that "neither the Sherman Act uor the Clayton Act confers on federal courts the broad power to formulate the right to contribution." Id. at 646 .

In Northwest Airlines, the Court similarly rejected the theory that it could use its authority to fashion federal common law remedies under the Equal Pay Act and Title VII of the Civil Rights Act of 1964. The Court lield:

The judiciary may not, in the face of such comprehensive legislative schemes, fashion new remedies that might upset carefully considered legislative programs.

...

... [W] are satisfied that it would be inproper for us to add a right to contribution to the statutory rights that Congress created in the Equal Pay Act and Title VII.

Northwest Airlines, Iuc. v. Transport Workers Uinon, 451 U.S. 77, $97-98$ (1981).

62. Chemung, 939 F.2d at 18.

63. Id. 
Court is limited to determining what Congress intended and only then, if a gap exists, filling in with development of a federal common law . . . . ${ }^{64}$

The reluctance of the courts to consider policy arguments, however, does not mean that such considerations are irrelevant. Leaving aside the issue of whether contribution under ERISA is a matter for Congress or the courts, the next two Parts analyze the policy considerations relevant to assessing the desirability of contribution among ERISA fiduciaries.

\section{II \\ CONTRIBUtion OR No CONTRIBUtion: THE EFFiciency Debate}

The primary objection to contribution is that it is economically inefficient. Indeed, any pohicy analysis of contribution would be incomplete without a discussion of the efficiency aspects of the proposed rule. While a detailed discussion of the legal literature addressing the efficiency of contribution rules is beyond the scope of this Comment, ${ }^{65}$ this Part outlines the economic aspects of the contribution debate in preparation for a discussion of the likely efficiency attributes of an ERISA contribution rule.

\section{A. The Economic Aspects of the Contribution Debate}

Two efficiency-based criticisms of contribution are advanced by lawand-economics commentators. The first criticism claims that contribution mcreases the cost of hitigation without a concomitant increase in deterrence. ${ }^{66}$ The second criticism argues that contribution discourages settlement, particularly under contribution regimes with low administration costs. ${ }^{67}$

\section{Contribution as an Inefficient Legal Rule}

In their groundbreaking work analyzing contribution ainong multiple tortfeasors, William Landes and Richard Posner concluded that a contribution rule is inefficient because, although the deterrent effects of a no-contribution rule and a contribution rule are the same, the latter is more expensive to administer. ${ }^{68}$

Landes and Posner's analysis is best demonstrated by an examina-

64. Narda, Inc. v. Rhode Island Hosp. Trust Nat'l Bank, 744 F. Supp. 685, 698 (D. Md. 1990).

65. The literature in this field is extensive and includes analyses of the efficiency of contribution in a number of statutory regimes. See supra note 20.

66. See William M. Landes \& Richard A. Posner, The Economic Structure of Tort LAW 201-02 (1987). 62.

67. See Easterbrook et al., supra note 20, at 362-64; Polinsky \& Shavell, supra note 20, at 459-

68. LANDES \& POSNER, supra note 66, at 201-03. 
tion of a basic simultaneous joint tort situation. Under standard tort law, a tortfeasor is not liable for damages under a negligence standard unless he or she fails to exercise due care. Due care is defined by economic theorists as the socially optimal level of care: that level of care that maximizes the benefit to society, taking into account the benefits derived by each tortfeasor froin not taking care and the social loss caused by the failures to use care. ${ }^{69}$

Without contribution, all parties involved in a joint tort situation have an incentive to select the socially optimal level of care. ${ }^{70}$ Each potential tortfeasor has an incentive to act with the level of care that minimizes the sum of his or her expected loss from liability (the full loss under no-contribution) and his or her cost of accident avoidance. Once one potential tortfeasor exercises care, the others have an incentive to do so because the tortfeasor who is negligent bears the total loss if the others are not negligent. ${ }^{71}$

Allowing contribution does not change this result. So long as the sum of all tortfeasors' expected sliares of the total loss is $100 \%$, the incentives for efficient accident avoidance are the same under contribution or no-contribution. ${ }^{72}$ Each tortfeasor will still exercise that level of care that minimizes his or her expected cost. ${ }^{73}$ Thus, in theory, a nocontribution rule and a contribution rule are equally efficient from a deterrence perspective. ${ }^{74}$

This theoretical view of the efficiency of contribution, however, ignores the transaction costs created by a contribution rule. ${ }^{75}$ According to Landes and Posner, ignoring transaction costs misses the picture: contribution is inefficient because it imposes additional transaction costs without affecting deterrence. ${ }^{76}$ "A rule that perınits contribution in any form entails costly suits among injurers ... [creatimg] ex post distributive consequences but no impact on incentives for efficient accident avoidance." ${ }^{17}$ Low transaction costs therefore make a no-contribution rule the most efficient system to achieve the socially optimal level of deterrence. ${ }^{78}$

69. Lewis A. Kornhauser \& Richard L. Revesz, Sharing Damages Among Multiple Tortfeasors, 98 YALE L.J. 831, 836 (1989).

70. LANDES \& POSNER, supra note 66, at 196.

71. Id.

72. Id. at 201 .

73. Id. at 196.

74. Id. This analysis assumes, however, that the parties are operating in a joint and several liability environment. Kornhauser \& Revesz, supra note 69, at 832; see LANDES \& POSNER, supra note 66 , at 196 n.8.

75. See Kornhauser \& Revesz, supra note 69 , at 842 (noting that "in this Article we assume the absence of insolvency and transaction costs").

76. LANDES \& POSNER, supra note 66, at 201-02.

77. Id. (footnote omitted).

78. Id. at 202. 


\section{Contribution as a Deterrent to Settlement}

The second criticism of contribution advanced by certain law-andeconomics scholars is that it tends to deter settlement. ${ }^{79}$ If contribution from settling defendants is allowed, settlement does not bar further hability and, according to the model, each defendant's incentive to settle decreases. ${ }^{80}$ A contribution rule therefore encourages every party to pursue litigation. ${ }^{81}$ Under a no-contribution rule, however, defendants will compete to settle rather than hitigate because the expected hability of the non-settling defendants imcreases as each defendant settles. ${ }^{82}$

A no-contribution rule also can create a "prisoner's dilemma" which tends to increase settlement amounts. ${ }^{83}$ In a multiple-defendant case, each defendant may know information that could help the plaintiff's case against other defendants. A defendant can therefore offer this private information to the plamtiff in return for a lower settlement. ${ }^{84}$ Because a settling defendant im a no-contribution regime faces no risk of later claims from non-settling defendants, each defendant has an imcentive to trade information in this manner. ${ }^{85}$ The plaimtiff therefore ends up with an mcreased total recovery.

A contribution rule, on the other hand, does not encourage this type of disclosure. Because a favorable settlement will not protect a defendant against later contribution clanns, disclosing critical information is always disadvantageous to defendants. ${ }^{86}$ Thus, the presence of a contribution rule has a negative effect on the plaintiff's recovery.

Law-and-economics scholars have acknowledged, however, that

79. See id. at 202-03. This criticism has been explored primarily in the antitrust area. See, e.g., Easterbrook et al., supra note 20, at 353-64 (exploring the economic effects of contribution rules on the rate and terms of settlement im antitrust cases); Polinsky \& Shavell, supra note 20, at 457-62 (considering the economic effects of a contribution rule on the parties' incentives to pursue litigation in antitrust cases).

80. LANDES \& POSNER, supra note 66, at 202; Easterbrook et al., supra note 20, at 365.

81. Only certain types of contribution rules produce this result. See infra note 87 and aecompanying text.

82. Easterbrook et al., supra note 20 , at 362 . A plaintiff is willing to settle with any given defendant for less than that defendant's proportional share of the danages so long as the plaintiff's expeetation of winning against that defendant is less than $100 \%$. Once a defendant settles with the plaintiff under a no-contribution rule, he or she cannot be forced to bear any additional share of the danages. Because the aggregate liability remains the same, the cost of not settling increases.

83. Jong G. Yi, Litigations with Multiple Defendants: How to Settle Under Different APportionment Rules 18-20 (Stanford University Center for Econoinic Policy Research Publication No. 225, 1990); see also Easterbrook et al., supra note 20, at 365.

84. YI, supra note 83 , at 19.

85. Conversations with attorueys who have practiced in states that do not allow contribution among multiple tortfeasors confirin that this type of settlement behavior is not uncommon. Interview with Scott A. Smith, Attorney at Law, Popham, Haik, Schnobrich \& Kaufman, Ltd., in Minneapolis, Minn. (Apr. 1992). Yi notes that a plaintiff in need of critical information may be willing to release or even bribe a defendant for the infornation. YI, supra note 83, at 19-20 \& n.14 (citing as an exainple Jones v. Hurst, 459 A.2d 219 (Md. Ct. Spec. App. 1983)).

86. YI, supra note 83 , at 20. 
contribution rules can be structured in a way that avoids the negative impact on settlement. A "carve-out" rule tliat reduces the potential liability of a non-settling defendant by settling defendants' sliare of damages (instead of by total settlements) produces the same incentive to settle as a no-contribution rule. ${ }^{87}$ A rule allowing contribution only froin non-settling defendants-called a "settleinent-bar" rule-likewise avoids the negative impact on settleinent. ${ }^{88}$

Some commentators argue, however, that these two contribution variations are unattractive. Carve-out rules that are easy to administer because they are based on equally apportioned hability negatively affect contribution's fairness objectives. 89 In addition, scholars criticize "fair" carve-out rules that apportion hability based on relative fault because they would probably be very expensive to administer due to the coinplexities involved in a judicial determination of fault. ${ }^{90}$ Many econoinists therefore prefer a no-contribution rule, which appears to present the most efficient option for the allocation of hability.

\section{B. Real-World Applicability of Economic Analysis: How the Validity of Underlying Assumptions Affects the Model's Normative Value}

While the law-and-economic theorists present a coinpelling theoretical case against contribution rules, their analyses rely upon several siguificant assuinptions. Several recent commentators, including Lewis Kornhauser and Richard Revesz of New York University ${ }^{91}$ and Jong Goo Yi of Stanford University, ${ }^{92}$ have undermined the validity of soine of those assumptions. Kornhauser and Revesz have challenged the assumptions that: (1) a neghigent actor is hable for the full loss caused by his or her actions; ${ }^{93}$ (2) negligent actors pay for damages that are

87. See Easterbrook et al., supra note 20 , at 363.

88. LANDES \& POSNER, supra note 66, at 203; Easterbrook et al., supra note 20, at 363.

89. Easterbrook et al., supra note 20 , at 365 . However, such rules would appear to be fairer than a no-contribution rule, under which a relatively minor player may be saddled with the entire liability. For a discussion of the faimess attributes of a contribution rule, see infra text accompanying notes 131-38.

90. Easterbrook et al., supra note 20, at 365-66. Interestingly, the authors retreat somewhat from this position in a footnote, where they admit:

Despite the observations in the text about the costs of administering a contribution earveout rule, we cannot be sure that it is more costly than the no-contribution rule. The nocontribution rule leads to sharing agreements, which are costly to reach and enforce, and it produces disutility to the risk averse, which is a real economic cost also.

Id. at 367 n.78.

91. See Kornhauser \& Revesz, supra note 69.

92. See YI, supra note 83.

93. Kornhauser \& Revesz, supra note 69 , at $837-40$ (arguing that a partial-liability rule is as applicable as a full-liability rule to situations involving multiple tortfeasors). Full liability occurs when negligent actors are liable for the full loss caused by their actions, while partial liability occurs when negligent actors are liable only for losses that could have been prevented by the exercise of due 
attributable to non-negligent actors; ${ }^{94}$ (3) damages are apportioned equally among negligent actors on a per capita basis; ${ }^{95}$ and (4) courts apply a socially optimal standard of care. ${ }^{96}$ Yi has focused on the model's assumptions that all hitigants have perfect information and that all defendants are solvent. ${ }^{97}$ These analyses suggest that deviations in the underlying assumptions from actual conditions reduce the policymaking value of efficiency analysis. ${ }^{98}$

Kornhauser and Revesz's critique suggests that any policy application of efficiency analysis should consider the possibility that the standard of care established by a given court often is not optimal. ${ }^{99}$ For example, a court-established standard of care inay deviate from the socially optimal level when the court has difficulty determining the benefits derived by the imjurer. ${ }^{100}$ An uncertain standard of care affects the accuracy of efficiency analysis. A perceived narrow variation may cause overdeterrence, while a perceived wide variation inay cause underdeterrence. ${ }^{101}$

The perfect information assumption noted by Yi also raises questions about the accuracy of the law-and-economics comparison of contribution and no-contribution rules. As Kornhauser and Revesz explam, a no-contribution rule is only efficient if "the sum of probabilities that the actors attach to the risks of being held responsible for the full damage [is] equal to at least one."102 The only way this can occur consistently is if

care. Id. at 837-38. Landes and Posner assume full liability in their analysis. See LANDES \& POSNER, supra note 66, at 521-23.

94. Kornhauser \& Revesz, supra note 69, at 841-42 (suggesting that damages could be based on a "fractional share rule," whicli would require negligent actors to pay only for the amount of damage that they cause).

95. Id. at $842-44$ (noting that damages could be divided according to a "proportional share" rule, under which negligent actors divide their hability according to their levels of care, instead of on a per capita basis). The per capita rule is a variation on the fixed-share rule, under which damages are apportioned independent of the level of care taken by the negligent actors. Id. at 843 . Kornhauser and Revesz interpret several antitrust analyses of contribution as using a per capita rule. See id. at 842 \& nn.51-52 (citing Easterbrook et al., supra note 20; Polinsky \& Shavell, supra note 20).

96. Kornhauser \& Revesz, supra note 69, at 862-63.

97. YI, supra note 83, at 2 .

98. See Edward D. Cavanagl, Contribution, Claim Reduction, and Individual Treble Damage Responsibility: Which Path to Reform of Antitrust Remedies?, 40 V AND. L. REV. 1277, 1280, 1307-09 (1987) (arguing that the value of theoretical contribution studies is limited because the conclusions of such studies are based on assumptions that do not necessarily mirror rcality).

Not all of the assuunptions discussed by Kornhauser and Revesz affect the efficiency assessment or, by extension, the real-world value of efficiency theory. Two assumptions fall into this category: full liability and per capita apportioument of damages. While these assuinptions seem worthy of critique, Kornliauser and Revesz's work suggests that deviations from these assumptions do not affect the value of the analysis. See Kornhauser \& Revesz, supra note 69, at 847.

99. Kornhauser \& Revesz, supra note 69, at 862-63.

100. Id.

101. Id. at $864-65$.

102. Id. at 861 . Landes and Posner base their analysis on the assumption that the probabilities will suin to one. Id. at 861 n.108 (citing LANDES \& POSNER, supra note 66, at 522). 
the actors have perfect knowledge: if each actor knows his co-actors' risk assessments. In the absence of perfect knowledge, different actors may attach inaccurate probabihties to their risk of hability and the probabilities may not sum to one.

The perfect information assumption also affects the model's predictive value with respect to settlement behavior. ${ }^{103}$ Intuitively, this result is easy to grasp. Assuming the contribution-settlement model is correct, all litigation under a no-contribution regime should settle. ${ }^{104}$ Obviously, this doesn't happen. Settlement negotiations arguably break down because of incomplete information. ${ }^{105}$ Yi's results suggest that, absent complete information, a no-contribution rule does not always increase the number of settlements. ${ }^{106}$ Thus, the model's predictive value is suspect in an imperfect information environment.

Fimally, the efficiency model's assumption that all defendants are solvent may affect the model's real-world apphicability. Yi's analysis suggests that the chance of settlement decreases when not all defendants are solvent. Insolvency himits the bidding contest, so the chances of going to trial increase. ${ }^{107}$ When some defendants are insolvent, therefore, the positive effects of a no-contribution rule on settlement will be less than predicted.

The reliability of the efficiency inodel as an accurate predictor of results thus depends on the validity of the assumptions embedded in the analysis. Yi and Kornhauser and Revesz suggest that the contribution/ no-contribution efficiency calculus may shift if certain of those assumptions do not mirror real-world conditions. The normative value of the model in a policy-settimg context hinges, then, on the validity of those assumptions.

\section{The Economic Efficiency of Allowing Contribution Under ERISA}

If we assuine that the efficiency model works in the ERISA context, a no-contribution rule appears to be the most efficient alternative. ${ }^{108}$ Applying that model, allowing contribution would not improve ERISA's deterrence characteristics, but would add coinplexity, increase litigation costs, and deter settlements. ${ }^{109}$ As noted above, however, the efficiency

103. YI, supra note 83, at 9.

104. See supra Section II.A.2.

105. YI, supra note 83 , at 9.

106. Id. at 21 .

107. Id. at 18 .

108. Of course, the model may not apply to the ERISA framework. The literature is bereft of any empirical data in this area, and law-and-economics scholars have not considered ERISA. Intuitively, however, it appears that ERISA fiduciary violations are similar enough to unintentional torts that the predictive value of the model should retain its vitality, absent any problems with the model's underlying assumptions.

109. See supra Section II.A. 
model is only helpful for policy setting if the underlying assumptions are correct. Intuitively, those assumptions seem particularly suspect with regard to ERISA. ${ }^{110}$

\section{The Effect of a Defendant's Insolvency}

The assumption that all defendants are financially capable of bearing the full measure of damages is questionable in antitrust situations, ${ }^{11}$ but is even less defensible im scenarios involving ERISA. Employee benefit plans are sponsored by both large and small employers. While smallness does not equate in ordinary circumstances with insolvency, losimg an ERISA fiduciary suit might be more likely to push a small company over the financial edge than a large company. Furthermore, a review of ERISA fiduciary cases suggests that many ERISA defendants are not major corporations but defendants with limited financial resources: individual trustees, small imvestment managers, and the like. ${ }^{112}$

The strong possibility of insolvent defendants im ERISA cases reduces the validity of efficiency-based arguments against contribution for two reasons. First, allowing contribution will not have the predicted adverse effect on settlement behavior. As noted above, if some of the potential defendants are imsolvent, the likelihood of settlement decreases and the predicted advantage of a no-contribution rule on settlements declines. ${ }^{113}$ Second, certain attributes of contribution may justify the increased administrative costs of contribution im an environment involving small or financially weak defendants. Allowing a named defendant to join a co-fiduciary through a third-party contribution action mcreases the pool of funds available to compensate a plan. ${ }^{114}$

110. Without empirical data, this discussion can only be cautionary: a yellow light rather than a red.

111. A no-contribution scheme may impair an antitrust defendant's ability to compete, financially ruin a defendant, or impair a defendant's ability to obtain credit by forcing disclosure of $100 \%$ of the potential liability as a contingent hability. Antitrust Damage Allocation: Hearings Before the Subcomm. on Monopolies and Commercial Law of the House Comm. on the Judiciary, 97th Cong., 1st \& 2d Sess. 141 (1981-82); The Antitrust Equal Enforcement Act: Hearings on S. 995 Before the Senate Comm. on the Judiciary, 97th Cong., 1st \& 2d Sess. 71-73 (1981-82) (statement of George Kress, Chairman of the Board, Green Bay Packaging, Inc.); Cavanagh, supra note 98, at 1290-91 (citing Committee on Antitrust and Trade Regulation, Report on Trebie Damages, 40 RECORD ASS'N BAR CITY N.Y. 647, 654-55 (1985) (on ability to compete)).

112. Chemung Canal Trust Co. v. Sovran Bank/Md., 939 F.2d 12 (2d Cir. 1991) (individual trustees), cert. denied, 112 S. Ct. 3014 (1992); Schloegel v. Boswell, 766 F. Supp. 563 (S.D. Miss. 1991) (individual insurance agent); see also Aiton Memorial Hosp. v. Metropolitan Life Ins. Co., 656 F.2d 245 (7th Cir. 1981) (individual pension consultant); Physicians Healthchoice, Inc. v. Trustees of the Automotive Employee Benefit Trust, 764 F. Supp. 1360 (D. Minn. 1991) (individual trustees).

113. See supra text accoinpanying note 107. As Yi explains, when one defendant is insolvent, the solvent defendant acts as though he or she were the only defendant. The incentive for a bidding contest is muted: the solvent defendant's incentive to make a high settlement offer -one that is high enough for the plaintiff to accept-is decreased when he or she does not have to worry about being "outbid" in the settlement game and forced to go to trial. YI, supra note 83, at 18.

114. In many instances, co-fiduciaries may carry malpractice or officers-and-directors insurance 
Contribution thus provides a cost-sharing and insurance mechanisin that protects planitiffs faced with small or financially weak defendants. In this respect, even a deterrence-neutral ERISA contribution rule is preferable to a regime under which a plan is denied an adequate financial recovery from breaching defendants.

\section{The Policy Implications of Imperfect Information}

The notion that litigants will have the perfect information required by the efficiency model seems farfetched. Yet the predictive value of the model depends on each actor accurately calculating the following factors: (1) the benefit of breaching: ${ }^{115}$ (2) the standard of care that will be imposed by the court; ${ }^{116}(3)$ the probability of getting caught and subsequently losing at trial; ${ }^{117}$ (4) his or her potential liability if the plaintiff prevails; ${ }^{118}(5)$ the likelihood that his or leer conipatriots will be nonnegligent or avoid liability; ${ }^{119}$ and (6) his or her coinpatriots' risk assessment. ${ }^{120}$ Accurately calculating even one of these factors would be a significant feat for a typical party to any form of significant civil hitigation.

Assuming that ERISA litigants have such perfect information is particularly questionable. ERISA cases typically involve evaluations of complex financial transactions. Not all ERISA fiduciaries have sufficient financial or investment acumen or regulatory knowledge to pohice their co-fiduciaries, mucli less estimate their co-fiduciaries' risk assessinent. ${ }^{121}$ In addition, the benefits of breaching ERISA's fiduciary requirements, except in cases of explicit intentional misappropriation, are extreinely difficult to quantify.

Imperfect information also affects a court's ability to identify the socially optimal standard of care and hence may induce under- or overdeterrence. If the court is unable to accurately determine the benefits derived by the breaching fiduciary, it may apply a suboptinal standard of care. ${ }^{122}$ Yet the court may face a magnified version of the benefit-quantification problem faced by the breachimg fiduciary.

This lack of perfect information seriously undermines the value of efficiency analysis in setting ERISA contribution policy. Not only inay fiduciaries fail to act in the predicted manner, but courts may establish

coverage. The broader the net, the broader the financial resources available to make the plaintiff whole.

115. Kornhauser \& Revesz, supra note 69 , at 836 .

116. Id. at $862-63$.

117. Id. at 861 .

118. Y1, supra note 83, at 47.

119. LANDES \& POSNER, supra note 66, at 195.

120. Kornhauser \& Revesz, supra note 69 , at 861 \& n.108.

121. See infra notes $165-66$ and accompanying text.

122. See supra text accompanying notes 99-101. 
and impose a non-optimal standard of care. Absent perfect information, a no-contribution rule is not necessarily more efficient, nor does it necessarily mcrease the likelihood of settlement. ${ }^{123}$ In the real world, the deleterious effects of a contribution rule predicted by the efficiency model may not materialize.

\section{The Limitations of Efficiency Analysis}

The economic attributes of contribution rules are only one of several considerations that should inform a policy choice about contribution. Landes and Posner's analysis was posited as a positive theory of tort law, not as a normative argument that tort law should be designed to promote efficiency. ${ }^{124}$ The authors themselves recognized that the efficiency model does not explain the trend away from the common law rule forbidding contribution. ${ }^{125}$

Other considerations must be factored into the contribution policy decision. The Supreme Court has stated that reducing complexity and encouraging settlements-the two advantages of a no-contribution rule advanced by law-and-economics scholars - do not by themselves justify a particular danage-apporionment rule. In United States v. Reliable Transfer $\mathrm{Co} .{ }^{126}$ the Court addressed the continuing validity of a rule that apportioned damages from maritime collisions equally between the responsible parties. ${ }^{127}$ The Court noted that "at bottom, [the argnment that the equally-divided-dannages rule promotes out-of-court settlements] asks us to continue the operation of an archaic rule because its facile application out of court yields quick, thougl inequitable, settlements, and reheves the courts of some hitigation."128 The Court rejected the efficiency argument and adopted a proportional fault rule, holding that "[c]ongestion in the courts cannot justify a legal rule that produces unjust results in hitigation simply to encourage speedy out-of-court accommodations." 129

Thus, there are two reasons that efficiency analysis alone should not drive policy decisions regarding the availability of contribution under ERISA. The first, articulated above, is that the assumptions underlying the economic models may be invalid in the ERISA context. The second, articulated by the Supreme Court, is that alternative considerations such

123. See supra notes $103-06$ and accompanying text.

124. See William Powers, Jr., On Positive Theories of Tort Law, 66 TEx. L. Rev. 191, 191 (1987) (reviewing LANDES \& POSNER, supra note 66).

125. LANDES \& POSNER, supra note 66, at 219.

126. 421 U.S. 397 (1975); see Texas Indus., Inc. v. Radcliff Materials, Inc., 451 U.S. 630, 646 (1981) (acknowledging the various arguments for and against contribution, but stating that the balancing sliould be done by Congress and not by the courts).

127. Reliable Transfer, 421 U.S. at 399-401.

128. Id. at 408 .

129. Id. 
as fairness should be factored into the analysis. The following section discusses the non-economic considerations that nust be addressed before setting ERISA contribution policy. It considers the provisions of the statute and their underlying policies in order to deinonstrate that (1) the unfairness of a no-contribution rule is magnified by ERISA's provisions, and (2) the risk of overdeterrence under a no-contribution rule offsets any inefficiencies that may be created by a contribution rule, given ERISA's public policy goals.

\section{III}

\section{CONTRIBUTION UNDER ERISA: FAIRNESS AND OVERDETERRENCE CONSIDERATIONS}

As a method of allocating damages, contribution involves certain procedural concerns and pohicy norms that must be considered in light of ERISA's underlying values prior to setting ERISA contribution policy. ${ }^{130}$ Those considerations have been articulated by state legislatures, courts, and Congress as they have wrestled with the issue of contribution m other contexts. This section focuses on two such considerations-fairness and overdeterrence-im the ERISA context.

\section{A. Fairness as a Justification for Contribution Under ERISA}

Perhaps the strongest and most frequent objection to the no-contribution rule is that it is unfair to defendants. Prosser and Keeton observed in an oft-quoted passage that:

There is obvious lack of sense and justice in a rule which permits the entire burden of a loss, for which two defendants were equally, umintentionally responsible, to be shouldered onto one alone, according to the accident of a successful levy of execution, the existence of hability insurance, the plaintiff's whim or spite, or the plaimtiff's collusion with the other wrongdoer, while the latter goes scot free. ${ }^{131}$

Although attempting to balance anti-contribution efficiency arguments against an unquantifiable characteristic like "fairness" is messy, ${ }^{132}$ fairness is a relevant consideration. ${ }^{133}$ Although there are trade-offs between efficiency and fairness goals, "[t]he domain of rights is part of the checks and balances on the inarket designed to preserve values that

130. See Donald J. Polden \& E. Thomas Sullivan, Contribution and Claim Reduction in Antitrust Litigation: A Legislative Analysis, 20 HARv. J. ON LEGIS. 397, 408 (1983).

131. W. Page Keeton et al., Prosser and KeEton on the LaW of ToRTS $§ 50$, at 337-38 (5th ed. 1984) (footnote omitted).

132. See Cavanagh, supra note 98 , at 1298-99.

133. See ARTHuR M. OKUn, EQUALITY AND EFFiciency 12-13 (1975) (noting that economic gain should not be the sole consideration in analyzing the value of social institutions). 
are not denominated in dollars."134

Fairness considerations have weighed heavily in instances where the courts or Congress have granted a right of contribution. The impetus behind abrogating the common law proscription of contribution in negligence actions has been a sense that it is unfair and unjust for one tortfeasor to bear the burden for all wrongdoers. Noting that they had "reputable coinpany" in abrogating the common law rule, the Third Circuit characterized contribution as a "rule of reasoned fairness," stating that " $[t]$ here is no longer a legitimate place in our system, if, indeed, there ever was, for a rule of law which places the full burden of restitution upon one who is only in part responsible for a plaintiff's loss."135

In a case involving a corporate breach of fiduciary duty, a Michigan district court held:

[T]o prevent a fiduciary . . . from seeking contribution . . . would result in a situation where, for example, two directors of a corporation are charged with the joint responsibility of selecting a inanager, and neither exercises reasonable care in carrying out this duty ... ; yet if the conduct of the manager causes a loss to the corporation, then, the plaintiff could choose to sue only one of the "fiduciaries", [sic] and the director sued could not seek to liave the co-fiduciary held equally responsible for their joint carelessness. Such a result would not . . . be equitable. ${ }^{136}$

Fairness has also been a key consideration in granting rights of contribution under the environmental and securities laws. The legislative history of the Superfund amendments suggests that Congress was concerned that the statute's potentially huge financial penalties be imposed fairly. ${ }^{137}$ Fairness arguments were also considered by courts inferring rights of contribution under securities law. ${ }^{138}$

The persistent role of fairness considerations in determining contribution policy in the courts, in the state legislatures, and in Congress suggests that efficiency arguments cannot be the sole basis of a policy choice

134. Id. at 13.

135. Gomes v. Brodhurst, 394 F.2d 465, 467 (3d Cir. 1967); see also id. at 467 \& n.l (citing cases from the District of Columbia, Iowa, Maine, Minnesota, Pennsylvania, Tennessee, and Wisconsin).

136. Federal Sav. \& Loan Ins. Corp. v. Quinlan, 678 F. Supp. 174, 176-77 \& n.2 (E.D. Mich. 1988). The facts of this case are strongly reminiscent of ERISA co-fiduciary situations.

137. See 131 CONG. REC. S12,008 (daily ed. Sept. 24, 1985) (comments of Sen. Domenici); Garber, supra note 20, at 373 (citing 131 CoNG. REC. 158 (daily ed. Dec. 5, 1985) (comments of Rep. Frank)); see also Developments in the Law-Toxic Waste Litigation, 99 HARV. L. REv. 1458, 1478 \& n.70 (1986) (citing H.R. REP. No. 1491, pt. 1, 94th Cong., 2d Sess. 17-24, reprinted in 1976 U.S.C.C.A.N. 6238, 6254-61).

138. See Huddleston v. Herman \& MacLean, 640 F.2d 534, 559 (5th Cir. Unit A Mar. 1981) (concluding that a rule permitting contribution provides an equitable result), aff'd in part and rev'd in part, 459 U.S. 375 (1983); McLean v. Alexander, 449 F. Supp. 1251 (D. Del. 1978) (stating that contribution is appropriate to limit the amount of loss to one's proportionate share), rev'd on other grounds, 599 F.2d 1190 (3d Cir. 1979). 
regarding contribution under ERISA. Fairness concerns must also be addressed before determining whether contribution should be allowed. ${ }^{139}$

I turn now to examine the particular fairness concerns that arise in the ERISA context, focusing on four specific areas: (1) ERISA's negligence-based standard of liability; (2) ERISA's standing provisions; (3) settlement practices in the ERISA context; and (4) ERISA's "outside expert" provision.

\section{A No-Contribution Rule Is Unfair Given ERISA's Negligence-Based Standard of Liability}

The most basic fairness concern raised by a no-contribution rule under ERISA involves the Act's standard of liability. ERISA has the same negligence-based standard of hability that the courts, Congress, and state legislatures have found incompatible with no-contribution rules in tort and securities law. Although certain violations under ERISA's cofiduciary hability provisions require intentional conduct, ${ }^{140}$ liability is generally imposed under ERISA's fiduciary rules for failure to meet a "prudent man standard of care."141 A fiduciary is charged with the responsibility to take those precautions and conduct those investigations that would be taken by a prudent person, and to seek outside advice if he or she is "ill-equipped" to carry out his or her responsibilities. ${ }^{142}$

To the extent that "fairness" implies an equating of fault and liability, it is unfair to prohibit a party who has been merely negligent from seeking contribution from other fiduciaries who may have been more at fault. If such a party is not allowed to seek contribution, there is no guarantee that the hability imposed on the party will be proportional to his or her degree of fault. Indeed, the Second Circuit has implicitly acknowledged this concept. In Chemung, one ERISA fiduciary sought to impose liability for an imprudent investment on a second fiduciary even though as inany as four fiduciaries arguably shared responsibility for the loss to the plan. ${ }^{143}$ The court reasoned:

139. Of course, while fairness and efficiency are admittedly not "wholly compatible ends," they do not necessarily point to different results. See Developments in the Law-Toxic Waste Litigation, supra note 137, at 1479 (discussing faimess and efficiency considerations in setting hazardous waste policy). To the extent that fairness equates with corrective justice-imposing the cost on the party that benefits from the activity-it is not inconsistent with efficiency's goal of internalizing the social costs of the activity. See id.

140. See 29 U.S.C. $§ 110 S(a)(1)$ (1988). A fiduciary may be liable for breaches by a co-fiduciary if the fiduciary "participates knowingly in, or knowingly undertakes to conceal, an act or omission of" the co-fiduciary. Id.

141. Id. $\S 1104$ (a) (1988 \& Supp. II 1990). Liability is also imposed for failure to adhere to plan documents. Id. § 1104(a)(1)(D) (Supp. II 1990).

142. Katsaros v. Cody, 744 F.2d 270, 279 (2d Cir.), cert. denied, 469 U.S. 1072 (1984).

143. Chemung Canal Trust Co. v. Sovran Bank/Md., 939 F.2d 12, 13 (2d Cir. 1991) (describing facts of the case and indicating that several fiduciaries may have been responsible, directly or indirectly, for the imprudent mvestments), cert. denied, 112 S. Ct. 3014 (1992). 
We see no reason to reject contribution as an equitable means of apportioning wrongdoing in this context.... [W]e think that even a breaching fiduciary should be entitled to the proteetion of contribution that has been traditionally granted fiduciary defendants under the equitable provisions of trust law. There is no reason why a single fiduciary who is only partially responsible for a loss should bear its full brunt. Full responsibility should not depend on the fortuity of which fiduciary a plaintiff elects to sue. ${ }^{144}$

This sense of fairness is in no way mconsistent with the fact that the fiduciaries seeking contribution may be considered wrongdoers. The apportioninent of liability accomphisled by a contribution mechanism would not affect ERISA beneficiaries, who would "continue to recover their full loss from any or all breaching fiduciaries, each of whom would be jointly and severally liable to the plaintiffs."145

If contribution is not allowed under ERISA, however, the fault-hability equation may be distorted. Witlout contribution, therefore, a fiduciary is at the mercy of the plaintiff's hitigation strategy. To the extent that one defines fairness as liability commensurate witl responsibility and accepts fairness as a relevant goal, forbidding contribution exposes a neghigent fiduciary to the risk of bearing an unfair burden.

\section{ERISA's Narrow Standing Provisions May Increase Procedural Unfairness Under a No-Contribution Rule}

ERISA's standing provisions are a significant procedural impediment to fiduciaries' ability to protect themselves agamst strategically filed lawsuits. The statute specifically einpowers three classes of individuals to bring civil actions under ERISA: plan participants and beneficiaries, the Secretary of Labor, and plan fiduciaries. ${ }^{146}$ These standing provisions liave been construed narrowly by the courts. ${ }^{147}$ As a result, once a fiduciary is removed from involvement with the plan, that fiduciary lias no standing to bring an action on behalf of the plan against current fiduciaries.

This limitation on standing applies even if tlie forner fiduciary had

144. Id. at 16.

145. Id.

146. See 29 U.S.C. § 1132(a) (1988 \& Supp. II 1990).

147. See Chemung, 939 F.2d at 14 (denying standing of former trustee to bring claim on behalf of the plan against current trustee for breach of fiduciary duties); see also Tuvia Convalescent Ctr., Inc. v. National Union of Hosp. \& Health Care Employees, 717 F.2d 726, 730 (2d Cir. 1983) (denying standing of enployer); Pressroom Unions-Primters League Incoine Sec. Fund v. Continental Assurance Co., 700 F.2d 889, 892 (2d Cir.) (rejecting standing of plan itself), cert. dismissed, 463 U.S. 1233, and cert. denied, 464 U.S. 845 (1983); Blackmar v. Lichtenstein, 603 F.2d 1306, 1310 (8th Cir. 1979) (rejeeting standing of former trustee to bring claim against current trustees). 
been removed specifically to prevent a threatened suit against the remaining fiduciaries. In Blackmar v. Lichtenstein, ${ }^{148}$ Blackmar was named sole trustee of two Liberty Loan Corporation employee benefit trusts. ${ }^{149}$ At the time of Blackmar's appointment both trusts were insolvent, and Blackmar immediately imstituted an action against the former trustees who were former Liberty managers. ${ }^{150}$ The day after Blackmar informed Liberty that he intended to amend the complaint to name Liberty as a defendant, he was removed as trustee. ${ }^{151}$ The court found that Blackmar's contention that Liberty violated its fiduciary duty by remov$\mathrm{mg}$ him to prevent the suit was not germane to the standing issue. It held that once the successor trustees were appointed Blackmar was no longer a fiduciary, and thus no longer had standing to sue on behalf of the plan. ${ }^{152}$

In light of ERISA's narrow standimg provisions, a no-contribution rule is manifestly unfair. A current plan fiduciary, fearing a suit by a cofiduciary, could renove (or mstigate the removal of) the co-fiduciary and then institute a legal action agamst the co-fiduciary for breach of fiduciary duties under ERISA. ${ }^{153}$ Absent a right of contribution, the defendant co-fiduciary-lackmg standimg to join the current fiduciary as a defendant on behalf of the plan-could be hable for all losses sustained by the plan if his or her own breach facilitated the loss in any way. ${ }^{154}$ Thus, a fiduciary may be maneuvered into bearing a burden that is disproportionate to his or her wrongdoing.

Even when ERISA's standing provisions are not employed strategically by a breaching co-fiduciary, those provisions may still produce an unfair result under a no-contribution regime. Although such a result was avoided in Chemung Canal Trust Co. v. Sovran Bank/Maryland because

148. 603 F.2d 1306 (8th Cir. 1979).

149. Id. at 1308.

150. Id.

151. Id.

152. Id. at 1310 .

153. Although the sponsoring corporation in Blackmar did not take legal action against Blackmar, the court's reasoning suggests that it would have strictly construed ERISA's standing provisions, regardless of the equities involved with respect to Blackmar himself:

If Liberty is in collusion with the successor trustees for an illegal purpose the successor trustees inay be held liable if they fail to carry on with any fiduciary obligations under the trust. ... [T] he beneficiaries or the Secretary of Labor can bring a civil action to properly protect the trusts. Id.

154. The extent of the former fiduciary's liability might, however, be limited in certain circumstances under ERISA's co-fiduciary provisions. See 29 U.S.C. $\$ 1105(c)(2)$ (1988). Notwithstanding those provisions, however, breaching co-fiduciaries are jointly and severally liable for all losses caused by their breaches. See id; see also Katsaros v. Cody, 568 F. Supp. 360, 369 (E.D.N.Y. 1983) (holding a trustec jointly liable with other trustees, even though the trustee was not present at the meeting where the offending transaction was approved), aff'd, $744 \mathrm{~F} .2 \mathrm{~d} 270$ (2d Cir.), cert. denied, 469 U.S. 1072 (1984). 
the court recognized a right of contribution, ${ }^{155}$ that factual setting illustrates the potential for unfairness.

In Chemung, the defendant fiduciary was the second trustee of an einployee retirement plan, appointed by the corporate plan sponsor after the initial trustee was removed for making imprudent investments and engaging in prohibited transactions. ${ }^{156}$ Although his predecessor inade the investinents, the defendant trustee was replaced by a third trustee when those investments turned bad. ${ }^{157}$ The third trustee brought an action against the defendant, alleging that the defendant's lack of prudence and due diligence with respect to the first trustee's investments was a breach of fiduciary duty. ${ }^{158}$ The defendant filed a counterclaim against the third trustee and a third-party coinplaint against the corporate plan sponsor for breach of fiduciary duty, requesting rehef on behalf of the plan and contribution or indemnity should he be found hable himself. ${ }^{159}$ Because the court held that the defendant lacked standing to sue on behalf of the plan, ${ }^{160}$ contribution was the only avenue available to apportion the plan's losses among all the culpable parties. ${ }^{161}$ Without a right of contribution, the defendant fiduciary in Chemung would have borne the financial burden of compensating the plan for losses sustained under the stewardship of four fiduciaries.

\section{A No-Contribution Rule May Facilitate Unfair Settlement Practices Under ERISA}

A no-contribution rule also promotes two types of unfair settlement conduct that are likely to occur in ERISA situations: collusive settlements between favored defendants and plaintiffs, and so-called "whipsaw" settlement tactics.

Protected by the fact that a co-defendant cannot recover additional damages post-settleinent, a favored defendant may agree to provide damaging information in exchange for a greatly reduced settlement or a proinise not to be named in the suit. ${ }^{162}$ Conversations with attorneys who have practiced in no-contribution jurisdictions indicate that such

155. See 939 F.2d 12, 16-18 (2d Cir. 1991), cert. denied, 112 S. Ct. 3014 (1992).

156. Id. at 13 .

157. Id.

158. Id. Under ERISA's co-fiduciary provisions, a fiduciary is liable for losses caused by a cofiduciary's breach if the fiduciary fails to prudently hire, monitor, or retain such fiduciary. See infra notes 177-83 and accompanying text.

159. Chemung, 939 F.2d at 14.

160. Id. at 15 .

161. Id. Theoretically, a defendant could approach plan participants and beneficiaries and encourage them to file claims against the other fiduciaries. However, plan participants and beneficiaries have no incentive to complicate the litigation by including other parties if the nained defendant has the financial ability to make the plan whole out of his or her own assets or through insurance.

162. See supra notes $84-85$ and accompanying tcxt. 
"side deals" do occur. ${ }^{163}$ Courts, too, have voiced concern about these practices. ${ }^{164}$

The circumstances are ripe for this type of conduct under ERISA. The world of small employee benefit plans is not characterized by the arms-length relationships and battalions of lawyers common in larger business dealings. Not all ERISA plan sponsors are major corporations who appoint trustees and hire investment managers based on qualifications. ${ }^{165}$ It is not uncommon for smaller organizations to appoimt business colleagues or personal acquaintances as plan trustees. ${ }^{166}$ If, aided by the negligent oversight of such a trustee, a plan's assets were unwisely invested, the sponsor would be predictably reluctant to extract a large settlement or judgment against the trustee if the plan could be made whole by tapping an unrelated co-fiduciary.

A no-contribution rule also permits use of "whipsaw" settlement tactics that force defendants to settle for ainounts that bear no relationship to their culpability or personal benefit. ${ }^{167}$ "Whipsaw" tactics work as follows: In a case involving numerous defendants, the plaintiff targets certain defendants, typically the deep-pocket defendants, and offers them favorable settlement terms. Those defendants settle for the discounted ainount, thus financing the plaintiff's continued litigation. Because the settlements are for less than settling defendants' share of the potential hability, non-settling defendants' exposure now exceeds their degree of responsibility. The risk faced by non-settling parties increases and the plaintiff's bargaining position improves. The process can be repeated through several rounds, with the stakes for non-settlers-and the asking

163. Interview with Scott A. Smith, Attorney at Law, Popham, Haik, Schnobrich \& Kaufman, Ltd., in Minneapolis, Minn. (Apr. 1992).

164. See Franklin v. Kaypro Corp., 884 F.2d 1222, 1227 (9th Cir. 1989) (discussing judicial criticisin of the no-contribution rule for "facilitating collusion between plaintiffs and wrongdoers"), cert. denied, 111 S. Ct. 232 (1990); see also Gomes v. Brodhurst, 394 F.2d 465, 468 (3d Cir. 1967) (discussing circumstances under which no right to contribution exists against settling defendants).

165. See, e.g., Katsaros v. Cody, 744 F.2d 270, 275 (2d Cir. 1984) (pension fund's Certified Public Accountant testified that "neither he nor anyone on the Fund's staff had sufficient training to express an opinion as to the soundness of [the challenged investment]. None of the trustees had an accounting or banking background. . . . They lacked any expertise in such important matters as capital adequacy, quality of assets, [and] hquidity . . . ."), cert. denied, 469 U.S. 1072 (1984). See Judy Greenwald, Debate Continues on Use of Outside GIC Management, BUS. INS., May 6, 1991, at 56-7 (discussing criteria to be used in selecting an investment manager).

166. See, e.g., Free v. Briody, 732 F.2d 1331, 1333 (7th Cir. 1984) ("[Trusteel was a lifetime friend of [sponsor's president] and did bnsiness with [him] in the role of an insurance agent .. . [and] served [him] as a direetor of several [of his] companies."); Blackmar v. Lichtenstein, 603 F.2d 1306, 1307-08 (8th Cir. 1979) (managers of corporate sponsor appointed as trustees).

167. See Cavanagh, supra note 98 , at 1290 . Cavanagh details the use of whipsaw settlement tactics in connection with the Corrugated Container antitrust litigation, where an unindicted company representing less than two percent of the sales in question was forced to choose between settling for $\$ 5.5$ inillion (7.5 times more per market share point than more culpable but earliersettling defendants) or risking a potential legal liability of $\$ 2-\$ 5$ billion. Id. at $1288 \mathrm{n} .67$ (discussing In re Corrugated Container Antitrust Litig., 84 F.R.D. 40 (S.D. Tex. 1974)). 
price for settlement-increasing each time. ${ }^{168}$

The threat of unfair settlement tactics in ERISA situations is not limited to cases between private litigants. Consider the Department of Labor's response to the Executive Life Insurance Company crisis. After Executive Life was seized, the Department warned companies that had replaced their pension plans with Executive Life annuities that they would be "sinart" to make up any losses caused by Executive Life's seizure. ${ }^{169}$ The Assistant Secretary of Labor was quoted as stating that companies' responses to the "demand letters" 170 would be "an important consideration in the government's decision whether to open full-fiedged investigations leading to possible lawsuits." ${ }^{171}$ Similar letters were sent to corporations with pensions backed by otleer insurers considered "dubious" by the Department. ${ }^{172}$ The Department adopted its posture despite the fact that Executive Life appeared to be in good financial condition when the annuities were purchased, ${ }^{173}$ and despite the fact that pension regulations encouraged companies to purchase annuities and required thein to "bid out" the business and accept the lowest price (i.e., highest rate) bid from a "responsible" company. ${ }^{174}$ In addition, corporate sponsors often employ professional investment managers, benefit consultants, and trustees to administer and manage their employee benefit plans. Forcing corporate sponsors to choose between guaranteeing their einployees' pensions or facing investigation and expensive litigation places them in a position of being forced to accept liability for others' actions regardless of their own culpability or the dictates of the statute itself. Absent contribution, the sponsoring company is powerless to recoup its losses from the specialists which it employed and upon which it relied. ${ }^{175}$

168. Id. at 1289.

169. Rosenblatt, supra note 3, at D1.

170. Robert A. Rosenblatt, U.S. Challenges Pension Switching, L.A. TimEs, June 13, 1991, at A1.

171. Rosenblatt, supra note 3, at D7 (construing statements of David G. Ball, Assistant Secretary of Labor).

172. Kathy M. Kristof \& Robert Rosenblatt, Executive Life's Fall Stirs Call to Protect Pensions, L.A. Times, June 16, 1991, at A1.

173. Id. (noting that Executive Life had been highly rated by the three most respected insurance company rating services).

174. Id.

175. The courts' broad construction of ERISA's preemption provisions, 29 U.S.C. $\$ 1144$ (1988 \& Supp. II 1990), virtually eliminates any non-ERISA-based avenues like breach of contract for recoupment. See, e.g., Mitnik v. Cannon, 784 F. Supp. 1190, 1194-95 (E.D. Pa. 1992) (holding that plan trustees' breach-of-contract claims against alleged fiduciaries were preempted); see also Ingersoll-Rand Co. v. McClendon, 111 S. Ct. 478, 482 (1990) (discussing the breadth of ERISA's precmption language). 


\section{A No-Contribution Rule Is Inconsistent with the Requirement that Plan Trustees Hire Outside Experts}

Managing and administering employee benefit plans is an expensive, regulation-intensive endeavor beyond the expertise of most sponsoring companies. Investing and inanaging millions of pension dollars is complicated, and the Department of Labor is increasing its scrutimy of investment decisions. ${ }^{176}$ Successive crises imduced by junk bond problems have shaken financial sectors such as insurance companies and thrifts that were previously perceived as stable. Safe but profitable investinent vehicles must be found for bilhons of employee benefit dollars.

Under ERISA's "prudent man" standard, fiduciaries who are "illequipped" to make these investment decisions are obligated to seek outside assistance. ${ }^{177}$ The outside assistance may involve obtaining information from qualified advisors ${ }^{178}$ or delegating authority for certain fiduciary responsibilities. ${ }^{179}$ Fiduciaries, lowever, are not absolved of responsibility or liability by delegating such autliority except in limited circuinstances. ${ }^{180}$

Fiduciaries have continuing responsibilities even if they obtain outside assistance. They are obligated to conduct independent investigations into the merits of proposed investments. ${ }^{181}$ They have ongoing responsibilities to: (1) prudently monitor the performance of appointed fiduciaries to ensure that the appointees' performance meets statutory requirements and the needs of the plan; (2) act dihgently and prudently by removing any appointed fiduciary who they determine is not properly carrymg out delegated duties; and (3) act prudently in delegating responsibilities to appointed fiduciaries. ${ }^{182}$ If the plan sustains losses as a result of a plan fiduciary's failure to fulfill these obligations, the plan fiduciary is jointly and severally liable for those losses even if the losses were

176. See supra text accompanying notes 171-74.

177. See Katsaros v. Cody, 744 F.2d 270, 279 (2d Cir.) (stating that ill-equipped trustees are under a duty to seek assistance), cert. denied, 469 U.S. 1072 (1984).

178. Katsaros v. Cody, 568 F. Supp. 360, 367 (E.D.N.Y. 1983), aff'd, 744 F.2d 270 (2d Cir.), cert. denied, 469 U.S. 1072 (1984).

179. 29 U.S.C. $\S 1105$ (c) (1988). A fiduciary's ability to delegate is constrained. A fiduciary may not delegate "trustee responsibilities," $i d$. $\$ 1105(\mathrm{c})(1)$, and may only delegate fiduciary responsibilities to the extent permitted by the plan documents, id. $\S 1105$ (c)(1)-(2).

180. See id. $\S 1105$ (a), (c)-(d). Section 1105 (d) provides that a trustee is not liable for the acts or omissions of a designated investment manager. Id. $\S 1105$ (d). The availability of the protection, however, is himited: the plan must exphicitly provide for the appointment of an investment manager, id. $\S 1105(\mathrm{c})(2)$; the investment manager must meet certain qualifying criteria, id. $\S 1002(38)(\mathrm{B})$; and the investment manager must acknowledge his fiduciary status in writing, id. $\S 1002(38)(C)$.

181. Donovan v. Cunningham, 716 F.2d 1455, 1467 (5th Cir.), cert. denied, 467 U.S. 1251 (1983).

182. See Schoenholtz v. Doniger, 628 F. Supp. 1420, 1428 (S.D.N.Y. 1986) (emphasizing that ERISA imposes an affirmative duty to act with diligence and prudence); 29 C.F.R. $\$ 2509.75-8$ at FR-17 (1991). 
directly caused by the actions of an appointed fiduciary. ${ }^{183}$

A no-contribution rule is inconsistent with the principles incorporated in these requirements. By implication, plan fiduciaries who must seek outside assistance are not sufficiently expert to inanage plan assets independently. By logical extension, they would tend to be susceptible to deception by the appointed "expert" fiduciaries. Without contribution, such fiduciaries would be required to seek outside assistance froin experts, but would not be allowed to allocate that portion of plan losses caused by the inadequate performance of those experts. ${ }^{184}$

\section{B. The Risk of Overdeterrence}

Anotlier disadvantage of an ERISA no-contribution rule is the risk of overdeterrence. A no-contribution rule may result in one fiduciary bearimg full liability, regardless of his or lier degree of culpability, opening the door to overdeterrence. In ERISA's dual-purpose environment, overdeterrence is a serious problem.

In developing ERISA's statutory structure, Congress sought to strike a balance between providing adequate protection for workers' retirement benefits and encouraging expansion of the private pension system. The Ways and Means Committee's report on ERISA noted that ERISA

encourages provisions for the retireinent needs of many millions of individuals. At the same time, the committee recognizes that private retirement plans are voluntary on the part of employers, and, therefore, it has weighed carefully the additional costs to the einployers and minimized these costs to the extent consistent with minimuin standards for retireinent benefits. ${ }^{185}$

The risks attendant to unnecessarily chilling employer-sponsored pension activity cannot be overstated: "Deinographic changes continue to place the Social Security System in a long-term financial crisis,"186 while the proportion of private retirement plan contributions provided by employees themselves lias decreased froin forty-two percent in 1940 to

183. See supra notes 15-16.

184. One could argue that potential plaintiffs have an incentive to name as many defendants as possible, and that such an incentive protects against this type of unfairness. This incentive, however, is illusory. As mentioned above, plaintiffs may favor some defendants by offering advantageous settlement terms in exchange for information. See supra text aceompanying notes 162-64. If the favored defendant is an expert, the likelihood that this defendant possesses valuable information is even greater. Furthermore, the assumption that plaintiffs have such an incentive is faulty if one of the potential defendants has sufficient assets to cover the total judgmeut. At that poiut, the incentive runs iu the other direction. By naming fewer parties, plaintiffs may be able to limit the complexity and expense of litigation.

185. H.R. REP. No. 807, 93d Cong., 2d Sess. 425 (1974), reprinted in 1974 U.S.C.C.A.N. 4639 , 4671.

186. Laurence J. Kotlikoff \& Daniel E. Smith, Pensions in the American Economy 1 (1983). 
six percent in $1980 .{ }^{187}$ As one legislator noted, "Realistically, social security by itself is not likely to provide enough for retirement income and the supplemental [private retirement] plans are very important."188

The likelihood of overdeterrence is greater when the activity being regulated is discretionary or has relatively limited utility to the actor. Consider the following: Assume that $X$ is the "good" behavior that we are seeking to encourage, and the benefit to Actor $A$ of doing $X$ is $B$. Also assume that twenty percent of the time, $A$ will do $X$ incorrectly, $Y$ will occur and $A$ will incur penalty $P$. $A$ will tend to do $X$ so long as $B$ is greater than the expected penalty (here, the expected penalty can be expressed as .20 times $P$ ). In general, the greater the benefit $B$ of doing $X$ (and thereby risking the chance that $Y$ will occur), the more likely $A$ will do $X$. For a given level of $P$ then, the lower the benefit $B$, the less likely $A$ will engage in $X$. As $P$ increases, the likelihood that $A$ will engage in good conduct $X$ decreases.

Applying this model to ERISA, certain aspects of employee benefit activity make overdeterrence more likely under ERISA than under other regulatory schemes. First, the benefit to a sponsoring company of maintaining ERISA retirement programs-typically, the ability to attract employees by offering competitive benefits ${ }^{189}$-is indirect and difficult to quantify. Second, except im the case of intentional misappropriation of plan assets, the profits to be garnered by a plan sponsor by breaching its fiduciary duties are limited. ${ }^{190}$ Since the incentive to breach one's fiduciary duty tends to be low, a high penalty is not necessary to deter breaches.

A no-contribution rule creates a higher potential penalty, as actors will be unable to spht the burden of liability among co-fiduciaries. A nocontribution rule therefore may overdeter corporate sponsors: the uncertain benefits of maintaining a private retirement program would be offset by potentially huge liabilities imposed as a result of otliers' actions.

While breaching fiduciaries must be held liable for tlieir actions, the imposition of penalties perceived as unfair or excessive may impede attainment of Congress' express goal of encouraging the formation and continuation of private employee benefit plans. Indeed, the widening reductions in medical and dental benefits demonstrates the vulnerability of benefit levels to increased costs. ${ }^{191}$ While the IBMs and AT\&Ts of the world will continue to sponsor employee benefit plans regardless of the

187. Alicia H. Munneli, The Economics of Private Pensions 53 (1982).

188. 120 CoNG. REC. 29, 210 (1974) (statement of Rep. Smith), cited in Laurence B. Wohl, Pension and Bankruptcy Laws: $A$ Clash of Social Policies, 64 N.C. L. REv. 3, 28 n.144 (1985).

189. Michael Bradford, In Future, Benefits Will Draw Workers, Bus. INS., May 6, 1991, at 27.

190. For example, a plan sponsor might breach its fiduciary duty of prudence by retaining an unqualified investment manager for a lower fee. The "profit" would be the fee saved by not hiring a more expensive, qualified party.

191. See Sabin Russell, Number of Uninsured Californians Likely to Rise 40\%, S.F. CHRON., 
contribution rules, small-to-medium-sized companies may decide that the financial risks created by a no-contribution rule outweigh the advantages of offering benefit plans. ${ }^{192}$

\section{IV \\ Legislative Trends: A Pro-Contribution Policy MOVEMENT}

The pohicy considerations invoked by the courts and Congress in analyzing contribution in other statutory regimes apply with varying force to ERISA. This section examines trends in tort law, securities law, environmental law, and antitrust law for evidence of a "statutory coinmon law" of contribution. ${ }^{193}$ To the extent that contribution policy decisions reflect certain characteristics of the underlying law, it is necessary to compare ERISA's structure and objectives with the structure and objectives of the various regimes. For example, is ERISA more like the Sherman Act or inore like CERCLA in the ways that seen important to the contribution debate?

\section{A. Statutory Common Law and the Value of Statutes as Expressions of Legislative Will Beyond Their Terms}

Although they constitute an ever-growing proportion of our law, statutes have rarely been accorded as extensive a role as case law in the

Sept. 6, 1992, at A21 ("Insurance costs continue to soar, making it unaffordable for many employers.").

192. Small-to-medium-sized companies seem most likely to employ outside experts to administer and to manage their employee benefit plans, least likely to have the information necessary to police these experts, and therefore arguably most likely to suffer the consequences of a nocontribution rule. See supra Section III.A.4.

193. The trends in corporations law toward broader and often mandatory imdemnification of officers and directors and toward application of the busimess judgment rule to shield directors' nonillicit actions are also animated by policy considerations similar to those present in ERISA. In general, corporate indemmification statutes strike a balance between protecting shareholders from breaches of fiduciary duty by their corporation's officers and directors and protecting officers and directors from substantial liability imposed on the basis of negligent behavior. One commentator has suggested that judicial application of the business judgment rule can be explanied by judicial conceru about the severity of sanctions and the accompanying risk that "ordinary standards of negligence would make it 'almost impossible to secure the services of able and experienced corporate directors.' " Stuart R. Colin, Demise of the Director's Duty of Care: Judicial Avoidance of Standards and Sanctions Through the Business Judgment Rule, 62 TEx. L. REv. 591, 628 (1983) (quoting Smith v. Brown-Borlek Co., 200 A.2d 398, 401 (Pa. 1964) (empliasis omitted)). At this point, all 50 states have passed indemnification statutes that establish the scope and terms under which corporations may or must indemnify officers and directors. Robert P. McKilmey, Special Project Note, Protecting Corporate Directors and Officers: Indemnification, 40 VAND. L. REV. 737, 737-38 (1987).

Althougl a complete comparison of the two statutory regimes is beyond the scope of this Cominent, the topic seems worthy of further study. Both the fiduciary responsibility segment of corporations law and the fiduciary conduct section of ERISA are rooted in cominon law trust principles. The evolution of this portion of corporations law may be a source of guidance for development of effective ERISA contribution rules. 
development of American law. ${ }^{194}$ As one modern commentator noted, "Statutes ... traditionally are thought to lack the persuasive secondary force exerted by cases. Statutes resolve disputes falling within their terms; statutes not apphicable by their terms, however, are regarded by many courts, lawyers and scholars as having hittle or no further use."195

The Supreme Court, however, has recognized the validity of using statutes to support legal reasoning that extends beyond their explicit terms. In Moragne v. States Marine Lines, Inc., ${ }^{196}$ the Court looked to state and federal statutes for evidence of a pohicy allowing recovery for wrongful death. ${ }^{197}$ In holding that a remedy for wrongful death was available under maritime law, the court noted that "numerous and broadly apphicable statutes, taken as a whole, inake it clear that there is no present policy against allowing recovery .... This legislative establishment of policy carries significance beyond the particular scope of each of the statutes involved."198

While much of the hiterature advocating the use of statutes for their persuasive potential focuses on common law decisionmaking, ${ }^{199}$ the same justifications apply to the use of existing statutes to guide policyınaking in other regulatory domains. Statutes are the result of discussion, negotiation, and coinpromise. ${ }^{200}$ If one statutory scheme articulates policy concerns applicable to another scheme, the balance struck in the one instance may be instructive in the second. As the Court noted in Moragne:

The legislature does not, of course, merely enact general policies. By the terms of a statute, it also indicates its conception of the sphere withm whicl the policy is to have effect. In inany cases the scope of a statute may reflect nothing inore than the dimensions of the particular problem that caine to the attention of the legislature, inviting the conclusion that the legislative policy is equally apphicable to other situations in whicls the mischief is identical. This conclusion is reinforced where there exists not one enactment but a course of legislation dealing witl a series of situations, and where the generality of the underlying principle is attested by the legislation of other jurisdictions. ${ }^{201}$

The applicability of this methodology to contribution policy is evident. Both state legislatures and Congress have considered contribution

194. See Landis, supra note 25 , at 214.

195. Williams, supra note 26 , at 555 .

196. 398 U.S. 375 (1970).

197. Id. at 390 .

198. Id.

199. See, eg., CAlABRESI, supra note 26; Landis, supra note 25; Traynor, supra note 26; Williams, supra note 26.

200. Williams, supra note 26 , at 557-58.

201. 398 U.S. at 392. 
policy in other statutory contexts. Thus, the answers to those policy puzzles can provide guidance in the analysis of contribution policy under ERISA.

\section{B. Statutory Trends in Contribution Policy}

Statutory developinent over the past sixty years has been characterized by a discernible legislative preference for contribution. Encouraged by the adoption by the Commissioners on Uniforn Laws in 1939 of the Uniforn Contribution Among Tortfeasors Act, state tort law has inoved steadily toward providing a right of contribution. ${ }^{202}$ On the federal level, Congress expressly permitted contribution under certain sections of the Securities Act of $1933^{203}$ and the Securities Exchange Act of 1934. ${ }^{204}$ More recently, Congress passed the Superfund Amendments and Reauthorization Act of 1986 (SARA), which expressly authorized contribution for habilities imposed under the Comprehensive Environmental Response, Compensation, and Liability Act (CERCLA). ${ }^{205}$ In addition, federal courts have recognized a right of contribution in cases involving admiralty, aviation collisions, employment discrimination, FELA claims, and securities fraud ${ }^{206}$ without subsequent congressional objection.

\section{State Tort Law and the Right of Contribution Among Multiple Tortfeasors}

Contribution between joint tortfeasors was not available at common law. The rule is said to have originated as a misinterpretation of Merryweather v. Nixan, ${ }^{207}$ an Enghish case that dealt with contribution among intentional tortfeasors. The rule was grounded in a refusal to allow an intentional tortfeasor to found an action based on his own dehiberate wrong. ${ }^{208}$ The rationale was that "the law should not lend its aid" to a tortfeasor by providing a means for him to coinpel others to share in the dainages. ${ }^{209}$ Even though changes im the rules of civil procedure resulted in the possibility of joinder of merely negligent tortfeasors, the rule against contribution annong joint tortfeasors was carried forth without change. ${ }^{210}$

The imitial abandonment of the common law rule against contribu-

202. Cavanagh, supra note 98 , at 1285 .

203. See 15 U.S.C. $\S 77 \mathrm{k}(\mathrm{f})$ (1988) (allowing contribution froin a person found liable for filing a false registration statement).

204. See id. $\S \S 78 \mathrm{i}(\mathrm{e}), 78 \mathrm{r}$ (b) (allowing contribution from a person found hable for manipulation of securities prices or for misleading statements, respectively).

205. See Garber, supra note 20 , at 365 (noting the exphicit recognition of contribution in the 1986 Act).

206. Cavanagh, supra note 98 , at 1286 .

207. 101 Eng. Rep. 1337 (K.B. 1799).

208. RESTATEMENT (SECOND) OF TORTS § 886A cmt. a (1979).

209. See Texas Indus., Inc. v. Radchiff Materials, Inc., 451 U.S. 630,634 (1981).

210. RESTATEMENT (SECOND) OF TORTS $§ 886 \mathrm{~A} \mathrm{cmt.} \mathrm{a} \mathrm{(1979).}$ 
tion occurred in situations involving tortfeasors who were not personally at fault, such as masters who were vicariously liable for their servants' torts, and in situations involving negligent tortfeasors. ${ }^{211}$

Indeed, most courts still refuse to allow contribution in cases mvolving intentional torts or willful, wanton, or reckless conduct, under the theory that willful wrongdoers should not be aided by the courts. ${ }^{212}$ This century nonetheless lias seen the adoption of contribution in eighty percent of the states and in the District of Coluinbia. ${ }^{213}$ Ten of these states' rules were initially fashioned through judicial action; the remainder were fashioned by the legislatures. ${ }^{214}$

The language of opinions addressing the issue of contribution evinces the evolution and adoption of policies informed by a concept of "fairness." The Supreine Court of New Jersey noted that "[c]ontribution has its roots in the equitable principle of equality among those in aequali jure, a sharing of the common responsibility according to equity and natural justice"215 and "is to be encouraged, as it is grounded in principles of fairness and equitable distribution of hability."216 In addressing whether to change froin a contribution rule based on pro rata liability to one based on proportional hability, the Wisconsin Supreme Court stated:

In discussing the right of contribution and its effect, we have often used such terms as his "fair and equitable share," "equity and natural justice," "Inore than his proportion," "more than his just share," and "inore than his proportionate share."

If the doctrime is to do equity, there is no reason in logic or in natural justice why the shares of common liability of joint tortfeasors should not be translated into the percentage of the causal neghigence which contributed to the injury. . . . It is difficult to justify, either on a layman's sense of justice or on natural justice, wliy a joint tortfeasor who is $5 \%$ causally neghigent should only recover $50 \%$ of the amount he paid to the plaintiff froin a cotortfeasor who is $95 \%$ causally negligent ....

... The function of law is to attain and maintain justice. No one denies the proposed change is more just in distributing the loss in proportion to the degree of negligence or fault which

211. Id.

212. Id. $\S 886 \mathrm{~A}$ cmts. $\mathrm{j}$, $\mathrm{k}$. The view that contribution is not allowed among intentional tortfeasors is not unanimous, however. See Judson v. Peoples Bank \& Trust Co., 110 A.2d 24 (N.J. 1954); Taylor v. Kinston Free Press Co., 75 S.E.2d 528 (N.C. 1953).

213. RESTATEMENT (SECOND) OF TORTS $§ 886$ A reporter's note (1982).

214. Id.

215. Sattelberger v. Telep, 102 A.2d 577, 584 (N.J. 1954).

216. Young v. Stemberg, 250 A.2d 13, 14 (N.J. 1969). 
caused it. ${ }^{217}$

The policy preferences implicated by this trend toward allowing contribution among unintentional joint tortfeasors are significant to the ERISA contribution debate for several reasons. First, ERISA's neghgence-based standard of liability is identical to that apphicable in multiple tortfeasor situations where contribution is permitted. In addition, the fairness issues concerning settleinent beliavior and allocation of losses based on proportional fault arise under both conventional tort law and ERISA.

Finally, tort law and ERISA have similarly competing goals. Under negligence law, the use of an objective standard of hability determined witl reference to a duty of care balances the need to deter socially disadvantageous conduct witl the need to avoid chilling economically beneficial conduct. ERISA's legislative history evinces a similar balancing approach: Congress atteinpted to protect private pension system assets witlout imposing costs that would discourage private employers froin expanding the systein. ${ }^{218}$

\section{The Right of Contribution Under Securities Law}

The federal securities laws provide a right of contribution to defendants in cases involving securities fraud, ${ }^{219}$ registration statement misrepresentations, ${ }^{220}$ security price mamipulation, ${ }^{221}$ and sale of unregistered securities. $^{222}$ With respect to certain types of securities violations, Congress expressly created the contribution rigltt. ${ }^{223}$ In other cases, however, the right has been judicially created. ${ }^{224}$

The securities laws provide a valuable source of guidance for setting

217. Bielski v. Schulze, 114 N.W.2d 105, 109 (Wis. 1962) (footnotes omitted), overruled on other grounds by Wangen v. Ford Motor Co., 294 N.W.2d 437 (Wis. 1980).

218. See supra text accompanying note 185 .

219. See Franklin v. Kaypro Corp., 884 F.2d 1222, 1226 (9th Cir. 1989) (allowing contribution in a securities fraud action under $\$ 10(\mathrm{~b})$ of the Securities Exchange Act of 1934), cert. denied, $111 \mathrm{~s}$. Ct. 232 (1990); Nelson v. Quimby Island Reclamation Dist. Facilities Corp., 491 F. Supp. 1364, 1383 (N.D. Cal. 1980) (allowing contribution in a securities fraud action under § 10(b), Rule 10b-5, $\S 17(\mathrm{a})$, and $\S 12(2)$ of the Securities Act of 1933).

220. 15 U.S.C. $\$ \S 77 \mathrm{k}(\mathrm{f}), 78 \mathrm{r}(\mathrm{b})(1988)$.

221. Id. $§ 78 \mathrm{i}(\mathrm{e})$.

222. Wassel v. Eglowsky, 399 F. Supp. 1330, 1366-67 (D. Md. 1975) (indicating that contribution is available in cases involving a sale of unregistered securities), aff'd, 542 F.2d 1235 (4th Cir. 1976).

223. See 15 U.S.C. $\$ 77 \mathrm{k}(\mathrm{f})$ (1988) (contribution available in cases involving filing of false registration statements); id. $\S 78 \mathrm{i}(\mathrm{e})$ (contribution available in cases involving manipulation of securities prices); id. \$78r(b) (contribution available in cases involving misrepresentations in registration statements or SEC filings).

224. See, e.g., Franklin v. Kaypro Corp., 884 F.2d 1222, 1222-23 (9th Cir. 1989) (finding an implied right of contribution in a securities fraud case brought under $\$ 10(\mathrm{~b})$ of the Securities Exchange Act of 1934), cert. denied, 111 S. Ct. 232 (1990); Sunith v. Mulvaney, 827 F.2d 558, 660 (9th Cir. 1987) (finding an implied right of contribution in a securities fraud case brought under \$10(b) of the Securities Exchange Act of 1934); Nelson v. Quimby Island Reclamation Dist. 
ERISA contribution policy. Indeed, a comparison of the securities laws with the structure of ERISA suggests that the two regimes share similar fairness and overdeterrence concerns. Thus, congressional and judicial preference for contribution in the securities context suggests that a similar approach might advantageously be adopted under ERISA.

The securities law contribution scheme is relevant to the ERISA contribution debate in part because of the standards of liability in the two statutory regimes. Like ERISA's fiduciary provisions, ${ }^{225}$ several provisions of the securities laws inpose liability for negligent conduct. ${ }^{226}$

This similarity suggests that the securities laws implicate the same fairness concerns that are imphicated under ERISA. ${ }^{227}$ At least one court inferring a right of contribution under the securities laws has recognized the significance of these fairness concerns. In considering whether contribution should be allowed in a section $12(2)$ securities fraud case, that court noted that "[a] joint-tortfeasor should not be allowed to escape hability under the Securities Act by the fortuitous circumstance that he was not sued in the main cause of action."228

The availability of contribution under the securities laws is even more significant when one considers that two of the provisions in the securities laws that contain congressionally created contribution rights require intentional action for the imposition of liability. ${ }^{229}$ Congress' express grant of these rights evinces a congressional policy in favor of hability apportionment through contribution regardless of degree of culpability. ${ }^{230}$ As noted above, fairness considerations are thought by some

Facilities Corp., 491 F. Supp. 1364, 1383 (N.D. Cal. 1980) (finding an implied right of contribution in a securities fraud case brought under $\S 12$ of the Securities Act of 1933).

225. For a discussion of the neghigence-based standard of liability inposed by ERISA, see supra notes $13,141.42$ and accompanying text.

226. See, e.g., 15 U.S.C. $\$ 77 \mathrm{k}(\mathrm{b})(3)(\mathrm{A})$ (1988) (any person other than the issuer alleged to be liable on account of a false registration statement is not liable so long as that person had, after reasonable investigation, reasonable grounds to believe that the statement contained no material oumssion or misstatement); id. $\S 77 /(2)$ (imposing hability on a person who sells or offers a security on the basis of a prospectus that contains a inaterial misrepresentation if such person does not sustain the burden of proof that he did not know, and in the exercise of reasonable care could not have known, that the prospectus contained an untruth or onission).

The standards of hability for violations of the Securities Act of 1933 and the Securities Exchange Act of 1934 do vary, though. A scienter requirement has been inposed for many violations, either expressly, see, e.g., id. § 78i(e) ("Any person who willfully participates in any act or transaction in violation of ... this section, shall be liable to any person who shall purchase or sell any security at a price which was affected by such act or transaction ...."), or by judicial interpretation, see Ernst \& Ernst v. Hochfelder, 425 U.S. 185, 214 (1976) (establishing a scienter requirement for $\S 10(b)$ violations).

227. See supra Sections III.A.1-4 for a inore detailed discussion of the fairness concerns miplicated by ERISA's standard of liability. Sinilar concerns have been invoked by courts in tort cases, see supra text accompanying notes 215-17, and in cases arising under CERCLA, see infra text accoinpanying notes $246-59$.

228. Getter v. R.G. Dickinson \& Co., 366 F. Supp. 559, 569 (S.D. Iowa 1973).

229. 15 U.S.C. $\S \S 78 i(e), 78 r(a)$ (1988).

230. Not all commentators agree. Despite the existence of these expressly granted contribution 
to weigh more heavily in favor of contribution in neghigence cases than im cases involving intentional conduct. ${ }^{231}$ If one subscribes to this view, this congressional policy decision is particularly persuasive when applied to ERISA, which generally establishes a neghigence-based standard of liability.

The securities laws are also analogous to ERISA because both statutes reflect a balancing of competing policy interests. As noted above, Congress enacted ERISA in order to achieve two fundamental goals: (1) to protect employee benefit plans by the imposition of uniform standards of fiduciary liability, and (2) to encourage the formation of private pension plans through the use of tax incentives. ${ }^{232}$ The federal securities laws demonstrate a similar duality: a desire to protect investors, coupled with a need to encourage capital formation.

Altlough the documentation of the legislative history of the securities laws has been described as "scanty,"233 a review of the developinent of those laws supports one commentator's view that "[t]he civil liability provisions of the federal securities laws reflect the competing desires to protect imvestors without creating in terrorum effects on legitimate commerce."234

For example, despite the fact that Congress enacted the Securities Act of 1933 in response to perceived "outrageous conduct" that contributed to the stock market crasli of $1929,{ }^{235}$ the first version of the Act was rejected by Congress in part because of its perceived negative impact on

rights, John Langmore and Robert Prentice maintain, without elaboration, that "[a]n examination of the Securities Act in general does not reveal any clear legislative policy favoring contribution." John H. Langmore \& Robert A. Prentice, Contribution Under Section 12 of the Securities Act of 1933: The Existence and Merits of Such a Right, 40 EMORY L.J. 1015, 1048 (1991).

Admittedly, Congress did not uniformly provide rights of contribution for securities law violators. Congress did not expressly create rights of contribution in section 12 of the Securities Act of 1933 or section 10(b) of the Securities Exchange Act of 1934. See 15 U.S.C. $\$ \S 77 \mathrm{e}, 78 \mathrm{j}(\mathrm{b})(1988)$.

This omission, however, does not necessarily reflect congressional hostility to contribution or a specific intent not to allow contribution unless expressly authorized in the applicable statute, notwithstanding the statutory construction maxim of expressio unius est exclusio alterius (literally, "expression of one thing is the exclusion of another," BLACK's LAw DictionaRY 581 (6th ed. 1990)). First, as Langmore and Prentice admit, "[T] he Supreme Court Justices embrace the expressio unius maxim when it suits their ends, and reject it when it does not." Langmore \& Prentice, supra, at 1040 n.133. Second, as one commentator has noted:

The absence of a contribution provision is understandable in sections $12(1)$ and $12(2)$; Congress probably assumed that only one person could be liable for a violation of those provisions since the language of those sections imposes liability on any person who sells a security in violation of the sections "to the person purchasing such security from him."

Loewenstein, supra note 20 , at 551 .

231. See supra text accompanying notes 212-17.

232. See supra text accompanying notes 10-11.

233. James M. Landis, The Legislative History of the Securities Act of 1933, 28 GEo. WASH. L. REV. 29, 29 (1959).

234. Michael J. Kaufman, The Uniform Rule of Liability Under the Federal Securities Laws: The Judicial Creation of a Comprehensive Scheme of Investor Insurance, 63 TEMP. L. REV. 61, 61 (1990).

235. Thomas L. Hazen, The Law of Securities Regulation $§ 1.2$, at 6 (1985). 
capital formation. ${ }^{236}$ The revised version focused simply on disclosure, not on any investment quality approval inechainsm. ${ }^{237}$ The concern with capital formation is reflected in a comment by one of the initial drafters of the legislation, who admitted that the 1934 amendments to the Securities Act of 1933 removed impediments to "the normal flow of capital into enterprise" caused by the original Act. ${ }^{238}$

This similarity is relevant because of the relationship between the balancing concerns of ERISA and the significance of overdeterrence arguments in determining contribution policy. As discussed above, overdeterrence is particularly troublesoine in the ERISA context because of the statute's dual purpose. ${ }^{239}$ The fact that Congress incorporated a right of contribution into the securities laws may reflect a heightened desire to avoid overdeterrence when confronted by such a dual purpose.

Finally, securities laws are similar to ERISA's fiduciary provisions in that both envision the possibility of numerous defendants. As already noted, ERISA's fiduciary provisions exphicitly recognize the participation of numerous fiduciaries in plan manageinent. ${ }^{240}$ Numerous parties may likewise be involved in a securities law violation. ${ }^{241}$

The possibility of inultiple wrongdoers in the securities context has been cited by commentators as a major reason to allow contribution in the securities fraud context. Adamski argues:

[I]t is irrational to compel one or inore defendants, who inay not have been the primary instigators of the fraudulent scheme, to bear the entire loss, while allowing other inore culpable wrongdoers to escape hability coinpletely. . . . Requiring one of many participants to pay the entire judgment inerely because the plaintiff, through oversight, whim, or collusion with other wrongdoers, fails to sue all of the wrongdoers would be an arbitrary and unfair inanner in which to redress violations of section $10(\mathrm{~b}) .^{242}$

This concern is echoed by Langmore and Prentice, who point out that considerations of friendship and blood relation affected the identities of the defendants in a inajor Supreine Court case involving the securities laws. ${ }^{243}$

These fairness considerations are relevant guides for ERISA contri-

236. See Landis, supra note 233 , at 32 (noting that the first bill proposed could have had "so dire and yet so unpredictable [an effect] that it [was] doubtful whether responsible investment bankers would have willingly chosen to subject theinselves to the possibility of its exercise").

237. Id. at 34 .

238. Id. at 40 n.18. Landis participated directly in the drafting of the 1933 Act.

239. See supra Section III.B.

240. See supra text accompanying note 17.

241. Adamski, supra note 20 , at 541 ("Nuinerous parties with varying degrees of participation in the fraudulent scheme may be responsible for a violation of section 10(b).").

242. Id. at 541-42 (footnote omitted).

243. Langmore \& Prentice, supra note 230, at 1062 n.245 (citing Pinter v. Dahl, 486 U.S. 622 (1988)). 
bution policy because the structural cliaracteristics underlying the fairness arguments in the securities context are identical to the structural characteristics at issue in ERISA. Not only does ERISA envision multiple wrongdoers, it also allows private parties to initiate legal action. ${ }^{244}$ Furthermore, the fiduciaries involved in an ERISA violation may have varymg degrees of participation and culpability. ${ }^{245}$ The fact that contribution is available for defendants under securities laws that sliare these characteristics indicates strongly that a similar remedy sloould be made available under ERISA.

\section{Rights of Contribution Under CERCLA}

When it enacted the Comprehensive Environmental Response, Cleanup and Liability Act (CERCLA) in 1980, Congress did not expressly provide for a right of contribution. ${ }^{246}$ Courts considering the issue after CERCLA's passage nonetheless inferred such a right from the legislative history of the statute. ${ }^{247}$ Congress later followed the courts' lead and explicitly incorporated a right of contribution into the statute with the enactment of the Superfund Amendments and Reauthorization Act of 1986 (SARA). ${ }^{248}$

The incorporation of a right of contribution into CERCLA is relevant to the ERISA contribution policy discussion for several reasons. The same joint and several liability structure tliat was an impetus behind judicial creation of CERCLA's right of contribution is mirrored in ERISA. Furthermore, several of the rationales advanced in favor of allowing contribution under CERCLA are equally applicable to ERISA.

Like ERISA, CERCLA imposes joint and several liability. ${ }^{249}$ Even de minimis contributors of hazardous waste to a site may be liable for the entire cost of cleanup under CERCLA. ${ }^{250}$ This similarity is relevant to ERISA contribution policy setting because of the importance of joint and several liability to congressional and judicial attitudes toward contribution under CERCLA.

\footnotetext{
244. 29 U.S.C. $\S 1132$ (a) (1988 \& Supp. II 1990).

245. See, e.g., supra text accompanying notes 155-58.

246. See supra text accompanying note 205 .

247. See, e.g., United States v. New Castle County, 642 F. Supp. 1258, 1266-67 (D. Del. 1986).

248. See 42 U.S.C. $\S 9613(f)(1)$ (1988).

249. United States v. Chem-Dyne Corp., 572 F. Supp. 802 (S.D. Ohio 1983) (establishing a presumption of joint and several liability in CERCLA cases).

Congress subsequently indicated its approval of Chem-Dyne's joint and several hability formulation during the debates on SARA. H.R. REP. No. 253(I), 99th Cong., 2d Sess. 74 (1985) (statement of Rep. Eckart that the bill was not "intended to change the application of the Federal rule of joint and several liability enunciated by the Chem-Dyne court"), reprinted in 1986 U.S.C.C.A.N. 2835, 2856; id. (stating that the House Committee on Energy and Commerce "fully subscribes to the reasoning of the court in the seminal case of United States v. Chem-Dyne Corporation, which establishes a uniform federal rule allowing for joint and several liability in appropriate CERCLA cases") (citations omitted).

250. See United States v. Conservation Chem. Co., 619 F. Supp. 162, 214-17 (W.D. Mo. 1985).
} 
Although Congress chose to have the courts address joint and several hability and contribution on a case-by-case basis rather than estabhishing the standards by statutory directive, ${ }^{251}$ CERCLA's legislative history suggests that Congress viewed contribution as an integral part of CERCLA's joint and several hability scheine. ${ }^{252}$ Contribution was viewed favorably because it balances the risk of one party bearing full liability with the opportunity for equitable apportionment. Indeed, statements made during debate suggest that soine niembers of Congress simply assumed that contribution would be available under the statute. ${ }^{253}$

Courts addressing the availability of contribution pre-SARA also focused on contribution's role in balancing the risks created by CERCLA's joint and several liability standard. ${ }^{254}$ In Colorado $v$. $A S A R C O$, Inc., ${ }^{255}$ the court noted:

CERCLA's primary goal is the expeditious cleanup of hazardous waste sites. Joint and several hability is a powerful tool to achieve that goal. It enables a plaintiff to select one primarily responsible party as the defendant ... and collect the total amount of damages froni that one defendant. . . . Once cleanup is assured, however, no goal of CERCLA would be promoted by requiring one of the responsible parties to continue to bear the full cost of injuries caused in part by others. ${ }^{256}$

Thus, both Congress and the courts apparently felt that contribution removed the rough edges fron the potentially draconian reinedy of joint

251. See Colorado v. ASARCO, Inc., 608 F. Supp. 1484, 1486, 1489 (D. Colo. 1985) (discussing the legislative history of CERCLA's liability provisions).

252. See 126 Cong. REc. 11,788 (daily ed. Dec. 3, 1980) (statement of Rep. Florio); see also United States v. New Castle County, 642 F. Supp. 1258, 1267 (D. Del. 1986) (noting that "[a]s floor manager of the House bill whicll was then under consideration, Rep. Florio's remarks regarding issues of CERCLA liability are deserving of substantial weight in a court's consideration of legislative listory"); Conservation Chem., 619 F. Supp. at 227 (recognizing that Congress contemplated the availability of contribution when it first passed CERCLA).

253. In his remarks regarding an amendment to one of CERCLA's precursor bills, Representative Gore noted that:

Under a sclieme of joint and several liability, where the defendants cannot themselves establislı their respective liabilities, eacli is responsible for the full amount, and the plaintiff may collect that full sum froin any one of them. The paying defendant would then have the riglit to go against the other "non-apportioned" defendants for contribution; the defendants would bear the burden of deciding who would pay how much to whom ainong them.

126 CoNG. REc. 26,785 (1980).

254. See, e.g., New Castle, 642 F. Supp. at 1266-67; ASARCO, 608 F. Supp. at 1491 ("[T]he majority rule allowing contribution among responsible parties is consistent with CERCLA's statutory purpose and sclieme."); see also Conservation Chem., 619 F. Supp. at 227 (stating that "[o]ther statements of House sponsors reveal a concern about making joint and several liability (and strict hability) more acceptable by allocating the burdens of CERCLA through a right of contribution").

255. 608 F. Supp. 1484 (D. Colo. 1985).

256. Id. at 1491 . 
and several liability. ${ }^{257}$ Indeed, Congress seems to have been motivated in part by fairness concerns when it adopted the contribution remedy as part of the 1986 amendments. ${ }^{258}$ Garber notes that "it appeared to many legislators that Congress had ridden rouglishod over small contributors and 'innocent' landowners."259

ERISA's joint and several liability standard implicates precisely the same concerns. The circumstances in Chemung demonstrate that ERISA's joint and several liability structure can have similarly harsh results if contribution is not allowed. ${ }^{260}$ The willingness of both Congress and the courts to focus on a fairness-based rationale in the CERCLA context should therefore be considered in the ERISA debate. As discussed here, that rationale leads to a conclusion in favor of allowing contribution under ERISA.

The more utilitarian arguments for contribution employed in the CERCLA context are also instructive here. Both ERISA and CERCLA contain strong enforcement goals. One of ERISA's stated goals is to increase the safety of employee benefit plans by imposing inore stringent and more uniform standards of conduct on plan fiduciaries. ${ }^{261}$ CERCLA likewise focuses on enforcement: its goals have been variously expressed as "encourag[ing] private remedial initiative," responsible for creating contamination problems bear the cost of cleaning them up."263

The behef that allowing contribution would augment enforcement efforts was a motivating factor belind the courts' creation of a right of contribution under CERCLA. One court speculated that contribution would facilitate the enforceinent of CERCLA by encouraging fingerpointing by defendants:

Because CERCLA liability is joint/several, the Government needs to sue only a limited number of responsible parties in order to recover all costs of cleanup and remedial operations at a site. Witlı a right to contribution available to CERCLA defendants, they will be willing to undertake the burden to locate and implead other responsible persons into a CERCLA action in order to inin-

257. This sense of balancing is explicit in a post-SARA case addressing the availability of a de minimis defense under CERCLA. O'Neil v. Picillo, 883 F.2d 176, 179 (1st Cir. 1989), cert. denied, 493 U.S. 1071 (1990).

258. See Garber, supra note 20 , at 373 .

259. Id.

260. See supra text accompanying note 144. ERISA's co-fiduciary provisions may in certain situations mitigate the type of risk inherent in CERCLA's strict liability/joint and several liability scheme.

261. See supra text accompanying notes 9-10.

262. AM Int'1 v. International Forging Equip., 743 F. Supp. 525, 527 (N.D. Ohio 1990).

263. Kyle E. MCSlarrow et al., A Decade of Superfund Litigation: CERCLA Case Law from 1981-1991, 21 Envtl. L. Rep. (Envtl. L. Inst.) 10,367, 10,388 (1991) (citing Chemical Waste Management, Inc. v. Armstrong World Indus., Inc., 669 F. Supp. 1285 (E.D. Pa. 1987)). 
imize their own liability. ${ }^{264}$

CERCLA's enforcement scheme is structured to overcome the difficulties of using traditional legal remedies. ${ }^{265}$ One of the motivations for the Superfund Program was that "it often proved difficult to determine which parties had contributed what share of the hazard to a given liazardous waste site" because the sites "received waste from many generators ... [and] were operated by several individuals or organizations through the course of the active operation."266 Joint and several liability allowed the Enviroumiental Protection Agency to declare one party fully responsible and impose the burden of establishing third party liability on the named party. ${ }^{267}$

Although there apparently are no einpirical data on the role of contribution in facilitating CERCLA enforcement, other data suggest that contribution assists enforceinent efforts. Identifying potentially responsible parties (PRPs) has been problematic for the EPA. ${ }^{268}$ A 1989 General Accounting Office report stated that the PRP search process "jeopardize[d] the success of EPA's Superfund enforceinent efforts."269 Some sites involve as many as 250 PRPs. ${ }^{270}$ Witl contribution, EPA can, and in fact does, concentrate its efforts on the largest parties, leaving it to those parties to pursue second-tier defendants. ${ }^{271}$ The contribution mechanism therefore seems to serve CERCLA's enforcement goal by identifying and imposing liability on the inaximum number of CERCLA violators.

ERISA's enforcement goal would be similarly served by incorporating a right of contribution. The incentive effects of combining joint and several liability with contribution would encourage private participation in ERISA's enforcement process by presenting defendants witl both the risk of complete liability and the partial protection of contribution. Defendants would have strong incentives to identify and share liability with otlier plan fiduciaries who violate the standards of conduct imposed by ERISA. ${ }^{272}$

264. United States v. New Castle County, 642 F. Supp. 1258, 1269 (D. Del. 1986).

265. JAN P. ACTON, UNDERSTANDING SUPERFUND 5 (1989).

266. Id.

267. Id. at 6 .

268. U.S. Gen. ACCOUNTING OFFICE, SUPERfund: A MORE Vigorous AND BetTer Managed Enforcement Program Is Needed 21 (1989) (Report to the Chairman, Subcommittee on Superfund, Ocean and Water Protection, Committee on Environnent and Public Works).

269. Id.

270. ACTON, supra note 265.

271. Jan P. Acton \& Lloyd S. Dixon, Superfund and Transaction Costs 10 (1992).

272. Furthermore, the information-access component that underlies CERCLA's contributionenforcement relationship also is present in the ERISA context. Trustees, sponsoring companies, or investment managers, because of both their specialized knowledge and their interlocking relationships, nay be in a better position to know all of the relevant facts than either the Department of Labor or plan participants and beneficiaries. See supra text accompanying notes 177-79. Thus, 
Finally, CERCLA and ERISA share one additional aspect that is relevant to the contribution policy debate: a strong correlation between fund-maximization and the effectiveness of the law. Under each statutory regime, the beneficial effects of the statute are maximized when the funds available for compensation are maximized. In the CERCLA context, greater compensation facilitates quicker and more effective environmental cleanups. Under ERISA, more compensation enhances the likelihood that the plan will survive and that the plan participants and beneficiaries will receive their benefits.

This pool-of-funds concept was used by one court as an argument in favor of contribution under CERCLA. In United States v. New Castle County, 273 the court reasoned that "[a]s the size of the defendant pool increases, the chances for settlement of the suit and achievement of one of the federal government's objectives under the Act-site cleanup at the expense of responsible parties-is met."274

The same reasoning is potentially more compelling in the ERISA context. Many ERISA fiduciaries are not huge financial entities, ${ }^{275}$ and the risk of a judgment-induced insolvency is not trivial. ${ }^{276}$ Although joint and several hability protects the ERISA plaintiff against the insolvency of one defendant, that protection is only of value when multiple defendants are nained. Thus, the availability of a contribution-driven incentive to "name names" may affect the size of the pool available to coinpensate the plan.

While the presence of strict liability lessens CERCLA's persuasive value when compared to the persuasive value of tort or securities law, 277 the parallels between CERCLA's structure and enforcement mechamisms and ERISA's structure and enforcement mechamisms are sufficiently strong that the rationales employed by the courts and Congress in adopting a right of contribution under CERCLA slould be considered in resolving the ERISA contribution issue. At the very least, the history of CERCLA's contribution remedy-the adoption by the courts followed by the exphicit incorporation by Congress-is consistent witl the trend toward allowing contribution that has occurred in tort law. That process itself suggests the existence of a pro-contribution policy on the federal level.

permitting contribution under ERISA should have the same favorable effect on ERISA euforcement by encouraging the cooperation of defendants.

273. 642 F. Supp. 1258 (D. Del. 1986).

274. Id. at 1269.

275. See supra text accompanying note 112 .

276. See supra text accompanying notes 111-19.

277. See supra text accompanying notes 212-18, 225-31. 
4. The Anomaly: Antitrust Law, the Courts, and the Refusal to Allow Contribution

Since the Sherman Act ${ }^{278}$ and the Clayton Act ${ }^{279}$ do not expressly provide a right of contribution, the question of availability of contribution under antitrust law was decided by the courts. In Texas Industries, Inc. v. Radcliff Materials, Inc., the Supreine Court refused to infer a right of contribution under the Sherman or Clayton Acts, holding that neither Act conferred on the federal courts authority to do so. ${ }^{280}$

Although the Court refused to adopt or reject the parties' policy argunents, the Texas Industries opinion hints at the Court's leanings. Responding to the argument that fairness and equity require a sharing of hability by all wrongdoers, the Court noted that such an argunient "presuppose[s] a legislative intent to allow parties violating the law to draw upon equitable principles to mitigate the consequences of their wrongdoing."281 The Court also noted that "equitable standards have soniething to say about the septic state of the hands of [a defendant seeking contribution]."282 In analyzing congressional intent, the Court considered the availability of treble damages as an indication of an intent to punish and deter unlawful conduct. ${ }^{283}$ Thus, the Court focused primarily on deterrence and expressed hittle concern for fairness considerations.

The absence of a right of contribution under antitrust law should not be interpreted, however, as a strong statutory precedent against allowing contribution under ERISA. First, although the Supreine Court in Texas Industries expressed concern about deterrence, the basis for the Court's refusal to imply a right of contribution was that it lacked the authority and power to do so. ${ }^{284}$ The decision was not reflective of contribution policy, but was based on a policy against judicial intrusion into the legislative arena. Thus, the value of the decision as an expression of contribution policy is weak. At its most powerful, this argunient merely implies that a contribution rule under ERISA should be legislatively enacted.

Second, unlike ERISA, unintentional tort law, CERCLA, and certain segments of securities law, antitrust liability requires intentional conduct. ${ }^{285}$ One caunot be neghigent or reckless and be guilty of anti-

278. 15 U.S.C. $\S \S 1-7$ (1988 \& Supp. III 1991).

279. Id. $\S \S 12-27,44 ; 29$ U.S.C. $\S \S 52-53$ (1988).

280. 451 U.S. 630,646 (1981).

281. Id. at 635 .

282. Id.

283. Id. at 639 .

284. Id. at 646 .

285. United States v. Bestway Disposal Corp., 724 F. Supp. 62,67 (W.D.N.Y. 1988) (stating that $\S 1$ of the Sherman Act requires a "preliminary showing that the defendants intended to form an agreement to violate" the law); J.H. Westerbeke Corp. v. Onan Corp., 580 F. Supp. 1173, 1188 (D. Mass. 1984) ("Monopolizing conduct is defined [under $\S 2$ of the Sherman Act] as intentional activity that tends to exclude competitors and is not necessarily required for socially approved 
competitive behavior. The neghigence-based standard that undergirds the fairness argument in ERISA, securities law, CERCLA, and other tort law is thus absent in antitrust law. Since fairness arguments may well be less compelling when the conduct is intentional, ${ }^{286}$ the signalling value of antitrust's no-contribution rule is substantially limited by the difference in hability standards. ${ }^{287}$

It is also difficult to compare antitrust law and ERISA from an effciency perspective. Like antitrust law-and unlike CERCLA-ERISA's fiduciary provisions and its legislative history focus on deterring "bad" behavior. ${ }^{288}$ In this regard, efficiency considerations appear to be as important to ERISA as they are to antitrust law. However, the difference in hability imposed by the two statutes evinces different attitudes toward deterrence. Unlike antitrust law, which imposes treble damages, ${ }^{289}$ ERISA's hability provisions focus on restitution and unjust enrichment. ${ }^{290}$ This difference suggests that efficiency/deterrence con-

competition on the merits."); see also Associated Gen. Contractors, Inc. v. California State Council of Carpenters, 459 U.S. 519, 547-48 (1983) (Marshall, J., dissenting) (suggesting that the concept of proximate cause is irrelevant in an action under section 4 of the Clayton Act since "it has always been assumed that the victim of an intentional tort can recover from the tortfeasor if he proves that the tortious conduct was a cause-in-fact of his injuries"). In fact, the courts have analogized antitrust violations to torts. As Justice Marshall observed, "antitrust violations are essentially 'tortious acts.' " Id. at 547 (quoting Karseal Corp. v. Richfield Oil Corp., 221 F.2d 358, 363 (9th Cir. 1955)).

286. See supra text accompanying notes 212-17.

287. Courts and legislatures still tend to retain the distinction between intentional and unintentional conduct. See supra text accompanying notes 212-14. Nonetheless, the distinction seems indefensible. The concept of "unclcan hands," used to justify the coinmon law nocontribution rule, was inplicitly discredited when the courts embraced contribution. Fairness considerations apply with equal force to intentional and unintentional tortfeasors. If more than one party takes part in an intentional wrong, allocating all of the liability to only one actor still means that liability will exceed responsibility, just as in the unintentional tort scenario.

In addition, the underlying basis for the distinction between intentional and urintentional wrongdoers-the maxim that parties should not profit froin their own wrongdoing-is inapposite. As two commentators addressing the availability of contribution under the seeurities law have pointed out, the argument that someone who has intentionally violated the law cannot appeal to our moral sense by claiming unfairness

is forceful to the extent that it supports a rule denying contribution to an intentional wrongdoer against an unintentional wrongdoer. ...

However, it is fair to allow intentional wrongdoers to seek contribution froin other intentional wrongdoers because their claim for compensation arises not from the wrong done to the plaintiff, but from the righting of that wrong. In essence, the party seeking contribution is asserting a claim not based on the wrong, but upon the satisfaction of the wrong.

Allowing contribution in such cases does not violate the maxim against allowing parties to profit from their own wrongdoing, because contribution plaintiffs are not seeking a positive gain, but ouly attempting to mitigate a loss.

Langmore \& Prentice, supra note 230, at 1068-69 (footnotes omitted).

288. See supra note 9 and accompanying text.

289. 15 U.S.C. $\S 15(\mathrm{a})(1988)$.

290. 29 U.S.C. $\S 1109$ (a) (1988) (requiring a breaching fiduciary to "make good to such plan any losses to the plan" and "restore to such plan any profits ... which have been made through use of assets of the plan by the fiduciary"). But see id. $\S 1131$ (1988) (authorizing imposition of fines or imprisonment for willful violations of Part 1 funding provisions). 
siderations should be accorded less weight in setting ERISA contribution policy than in setting antitrust contribution policy.

One efficiency consideration advanced in favor of contribution under antitrust law is relevant to an ERISA analysis: the problein of overdeterrence. Altliough the Texas Industries Court declined to infer a right of contribution under the Sherman or Clayton Acts, the Court recommended that the risk of "overdeterrence" "by imposition of severe penalties be weiglied in the contribution analysis. ${ }^{291}$

Soine imight view the ongoing failure of Congress to create a right of contribution under antitrust $\mathrm{law}^{292}$ as evidence of congressional lostility to contribution or a lack of concern about overdeterrence that slould be given effect in setting ERISA contribution policy. This view, however, ignores the inost significant difference between antitrust laws and ERISA: congressional balancing of conflicting objectives.

Congressional intent to accomplisl two objectives is evident in the case of ERISA. A review of the legislative history of ERISA shows that, while the inain impetus for enacting ERISA was to protect plan participants from fiduciaries who abused their trust, ${ }^{293}$ a secondary goal was expansion of the private pension systein to augment Social Security. ${ }^{294}$

In the case of antitrust law, the case for a dual purpose is weaker. While it is true that antitrust laws are currently being interpreted so as to deter anticompetitive behavior witlout "chilling" legitinate business conduct, the predommant impetus for initial passage of laws was trustbusting. ${ }^{295}$ Concerns about "chilling" legitimate business practices have only surfaced in recent years. ${ }^{296}$

To the extent that balancing is desirable, it has been accomplished by other means in the antitrust context. For example, the Supreine Court's shift to rule of reason analysis from per se doctrine has "refocus[ed] the inquiry on the adverse economic effects, and the potential economic benefits," of the cliallenged conduct. ${ }^{297}$ Furthermore, the executive brancli's lostility to antitrust claims of all sorts is no secret. ${ }^{298}$

291. Texas Indus., Inc. v. Radcliff Materials, Inc., 451 U.S. 630, 637 (1981).

292. See, e.g., id. at 645 ("[T]he continuing existence of this statutory scheme for 90 years without amendments autlorizing contribution is not witlout significance.").

293. See supra notes 7-10 and accompanying text.

294. See supra note 11 and accompanying text.

295. A. D. Neale, The ANtitrust Laws of the United States of America 23-30 (1966). "[T] he paramount aim of the Sherman Act at the start was to meet the public demand that the Federal Government should 'do something about the trusts'. [sic]" Id. at 27.

296. See, e.g., Matsushita Elec. Indus. Co. v. Zenitl1 Radio Corp., 475 U.S. 574, 593-94 (1986) (limiting the range of permissible inferences about price-cutting conspiracies out of concern for the chilling effect of mistaken inferences).

297. Jefferson Parisl Hosp. Dist. No. 2 v. Hyde, 466 U.S. 2, 35 (1984) (O'Connor, J., concurring).

298. Whether this hostility will persist during the Clinton Administration is uncertain. If antitrust violations are pursued more vigorously, the antitrust contribution debate may be revived in Congress. See supra note 130 . 
In an environment where the courts and the agencies are not particularly zealous in applying antitrust law, Congress has little reason to worry about overdeterrence, much less contribution. In essence, the "unfairness" of the lack of contribution is irrelevant because the enforcement standards themselves have been changed.

The failure of Congress or the courts to graft a right of contribution onto the antitrust laws therefore does not represent a break in the statutory trend toward contribution. Instead, the lack of contribution reflects differences in policy and structure between ERISA and other statutory regimes. In addition, the impetus to remedy any perceived problems witl the no-contribution rule ${ }^{299}$ lias becn reduced by otlier changes in the enforcement and interpretation of the antitrust laws.

\section{CONCLUSION}

The desirability of allowing contribution between co-fiduciaries under ERISA is not an easy issue to resolve, especially without reliable empirical economic data. There are serious efficiency-based arguments against allowing contribution. Contribution rules add coinplexity. They increase litigation costs. They may lessen deterrence and discourage settlements. These arguments should not be lightly dismissed.

On the other hand, fairness considerations abound in the ERISA context. The structure of the statute itself-negligence-based liability, narrowly drawn standing, overlapping fiduciary duties, private and pubhic enforceinent-inay exacerbate the potential unfairness of a no-contribution rule. Coinplicating the analysis further is ERISA's dual purpose of encouraging private pension plans while discouraging fiduciary misconduct. In the end, however, the balance between efficiency and fairness considerations rests in favor of granting ERISA fiduciaries a riglit of contribution.

From the fairness perspective, the case for some type of ERISA contribution rule is compelling. To begin witl, ERISA has for the inost part a negligence-based standard of liability. Witlout tlie ability to sliare liability through a contribution action, a negligent ERISA fiduciary may bear the entire liability burden even though his or her co-fiduciaries were more culpable. While imposimg liability disproportionate to responsibility is arguably unfair whetlier the liability is imposed for intentional or neghigent conduct, it is particularly unfair when the triggering conduct was simply negligent.

ERISA's narrow standing provisions exacerbate the problem. Because only plan fiduciaries, plan participants, plan beneficiaries, and the Secretary of Labor have standing to bring an ERISA action, a co-

299. See Polden \& Sullivan, supra note 130, at 403-08 (describing various legislative proposals to create a federal right of action for contribution). 
fiduciary can preemptively fire a fiduciary threatening to sue for breach of duty, and then bring an action agamst such a fiduciary. Because a forner fiduciary has no standing to bring an ERISA action, a no-contribution rule blocks the last avenue of defense available to the terminated fiduciary, who may not have been solely at fault.

A no-contribution rule also facilitates collusive settlement practices. Favored fiduciary defendants can be offered advantageous settlements (assuming they are named in the first place) without facing additional hability through contribution. The risk of this type of outcome seems increased in the ERISA context: the Secretary of Labor's settlement strategy may be motivated by pohtical concerns, and private plaintiffs may be faced with the choice of imposing hability on a less culpable stranger or on an equally or more culpable colleague. Because ERISA usually imposes joint and several hability, a plaintiff's settlement strategy need not affect his or her ultimate recovery. Without recourse to contribution, the disfavored fiduciary may be forced to shoulder a proportion of the total hability completely unrelated to his or her own fault.

Fimally, a no-contribution rule is unfair in the context of ERISA's requirement that inexpert fiduciaries retain outside experts. Plan fiduciaries who are ill-equipped to make investment decisions are required to retain outside assistance. Although plan fiduciaries may delegate certain responsibilities, they are not absolved of responsibility to momitor the expert's actions and decisions. Without contribution, ERISA creates an unfair dynamic: fiduciaries who are least equipped to oversee the conduct of outside "experts"- and therefore most susceptible to being deceived-are required to hire those experts, but are unable to protect themselves against bearing the full burden of any plan losses caused by those experts.

As the ERISA cases discussed above demonstrate, these fairness concerns are not miaginary bogeymen. Co-fiduciaries do use the structure of the statute to obtain unfair tactical advantages. Defendant fiduciaries like the one im Chemung are exposed to liability disproportionate to their fault. ${ }^{300}$ Fiduciaries like Blackmar in Blackmar v. Lichtenstein are prevented from implicating breaching co-fiduciaries by strategic termination. ${ }^{301}$

These very real opportunities for unfairness in an ERISA no-contribution regime must be weighed against some theoretical, unproven inefficiencies in deterrence and settlement and some real inefficiencies in the forn of increased costs and complexity. The policymaking guidance that can be gleaned from the traditional efficiency model is limited in the ERISA context. The model was not intended as a nornnative model in the first place. In addition, its predictive value is suspect in the ERISA

300. See supra text accompanying notes 155-61.

301. See supra text accompanying notes 148-54. 
context because of the inapplicability of certain underlying assumptions. In the end, the contribution-opposing results of traditional efficiency analysis are an insufficient reason to impose substantial unfairness on ERISA fiduciaries.

An ERISA contribution rule inay not liave tlie deleterious effects on deterrence and settlement predicted by the efficiency model. The model's assumptions do not mirror the real-world conditions faced by ERISA actors. An ERISA fiduciary is not likely to liave the myriad pieces of information necessary to minimize liability losses: lie may clioose to be under- or over-careful froin a societal perspective. Furtliermore, not all potential ERISA defendants are solvent. Yet, according to its critics, the efficiency inodel's predictions of inefficiency and reduced settlement depend on the validity of these assumptions.

Nonetheless, a contribution rule inay add cost and coinplexity to ERISA litigation. A named defendant fiduciary would be able to join additional fiduciaries as parties, increasing the scope of the hitigation. The administrative burden on the courts may increase.

These costs alone do not provide a compelling reason to impose significant risks of unfairness on ERISA fiduciaries. First, there are contribution policy variations that offset the various anti-contribution rationales. Alternative contribution rules, settleinent bars, and the likeall beyond the scope of this Comment-could be utilized to limit the negative aspects of an ERISA contribution rule. Furthermore, fairness is a value that runs consistently and deeply througli our legal systein. As the Supreme Court held in United States v. Reliable Transfer Co., reducing coinplexity and encouraging settlements do not by theinselves justify an unfair rule. ${ }^{302}$

The balance is further shifted in favor of contribution when one considers the dual purpose of ERISA. As noted above, Congress atteinpted to balance in ERISA the need to protect employees' pensions with the need to encourage private compames to expand private pension coverage. Overdeterrence is particularly troublesoine in this competing-purpose environment. Yet the risk of overdeterrence, inherent in any no-contribution regime, is particularly problematic in the ERISA context. The possibility that a company could face a large loss due to another party's conduct inay inore than offset the amorphous and uncertam value of offering the benefit plan in the first place. At least in the case of ERISA, the combination of fairness and overdeterrence considerations inore than offsets the complexity and cost issues.

Granting ERISA fiduciaries a right of contribution is also consistent with current trends in state and federal contribution policy. In the tort law arena, the vast inajority of states-cighty percent, and the District of

302. See supra text accompanying notes $126-29$. 
Columbia-have abandoned the common law no-contribution rule in favor of allowing contribution between joint unintentional tortfeasors. On the federal level, there is a strong pro-contribution orientation. Rights of contribution are available under admiralty, aviation, employment discrimination, FELA, environinental, and securities laws. The much-discussed proscription of contribution in antitrust law derives from sources unrelated to current legislative preferences.

To the extent that these statutes represent an articulation of policy applicable beyond their terms, the availability of contribution in these legal regimes may be persuasive evidence in favor of contribution in the ERISA context. If there are similarities in the problems or issues addressed, the policy choices made in those areas are appropriately used as guidance in the ERISA contribution policy analysis. The persuasive value of those clioices increases to the extent that ERISA shares structural characteristics with those statutes.

A detailed assessinent of the structure and motivatimg goals of four of the above-noted regimes-tort, securities, environinental, and antitrust-supports allowing contribution among ERISA fiduciaries. The values and issues informing the pro-contribution policy choices in tort, securities, and environmental law are present in the ERISA context. In addition, these regimes share with ERISA certain structural attributes relevant to contribution policy. By contrast, the underlying issues and structural characteristics im antitrust law are less analogous.

The fairness concerns that I argue should inform the ERISA contribution decision lave been driving forces in tort law, securities law, and CERCLA. The existence and persuasive effect of those concerns are evident $\mathrm{m}$ both judicial and legislative statements regarding the availability of contribution in those areas. The sentiment that legal liability should be proportionate to legal responsibility flows consistently through the cases and the legislative history addressing each regime's contribution rule.

Many of the structural characteristics relevant to the fairness calculus are present in tort law, securities law, and CERCLA, just as they are present in ERISA. ERISA shares its predominately negligencebased standard of liability with tort law (taking into account the usual limitation of contribution to torts that are umintentional) and with soine areas of securities law. Further, the securities laws and CERCLA, like ERISA, allow botl public and private enforcement. All three anticipate the possibility of numerous defendants. The concomitant potential for coercive settlement tactics and strategic defendant selection, noted as possibilities in the ERISA context, have motivated the pro-contribution policy choices made in securities law and CERCLA. CERCLA and ERISA share jomt and several liability, a structural attribute that significantly augments the unfairness of a no-contribution rule. 
CERCLA contribution policy is relevant to the ERISA contribution discussion for yet another reason: ERISA and CERCLA share the goal of maximizing the funds available to remedy the wrong. One of the stated rationales for allowing contribution among CERCLA defendants was the need and desire to use those defendants to identify other responsible parties, and maximize the potential recovery. This indirect benefit of contribution is no less important in the ERISA context: not only may information about co-fiduciaries' breaclies be more readily available to a co-fiduciary, but any single fiduciary may lack the wherewithal to fully compensate the plan.

Overdeterrence, another issue relevant in setting ERISA contribution pohicy, is also a factor in securities and tort law contribution policy. Like ERISA, those areas of the law are cliaracterized by a balancing of the need to deter "bad" behavior with a desire to promote "good" behaviors. That balancing act requires particular care in the formulation of sanctions. No-contribution rules, with their "loser loses all" implications, can result in disproportionate, overdeterrence-producing penalties.

All this is not to say that ERISA shares every relevant structural characteristic of these four regimes. Some of the differences cut in favor of the statutory analogy, some against. Weakening the CERCLA "fit," CERCLA imposes strict hability, which presents a more powerful fairness rationale than that available under ERISA's negligence-based standard. On the other hand, contribution is allowed for certain securities violations, despite the restriction of hability to intentional conduct. On the whole, though, the relevant issues, values, and structural characteristics are sufficiently analogous that the existence of contribution rights in these diverse areas of federal and state law is a persuasive argument in favor of granting a right of contribution to ERISA fiduciaries.

What about antitrust law? The antitrust no-contribution rule at present appears to be less a statement of anti-contribution sentiment on the part of Congress and the courts than a refiection of both the Supreme Court's judicial restraint and the evolution of hability-reducing antitrust doctrimes. Furthermore, antitrust's defining cliaracteristic-the availability of treble dainages-evidences a primacy of deterrence and enforceinent considerations over fairness and overdeterrence considerations. The saine primacy is not evident in ERISA's structure. In all, the analogy between ERISA and antitrust law is sufficiently weak to discount the antitrust policy choice when setting ERISA contribution policy.

Granting ERISA fiduciaries a right of contribution to equitably apportion hability is consistent with the norm of fairness interwoven in federal and state law. It is also consistent with ERISA's dual purpose. Integrating a contribution rule into ERISA would harmonize ERISA's contribution pohcy with current pro-contribution legislative preferences. The pro-contribution pohicy evidenced in numerous inulti-defendant 
regimes should not be ignored. Whether the authority to incorporate a right of contribution lies with the courts or with Congress I have left for others to resolve. There can be no doubt, however, that the time has come to clear up the present confusion. 